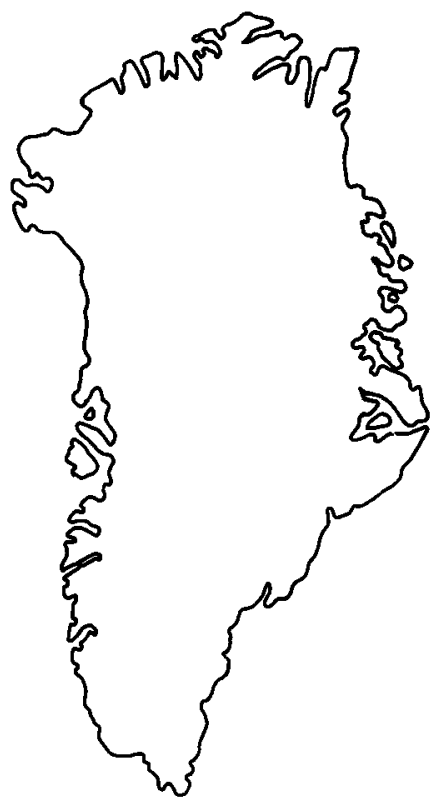

\title{
Trace fossils from the Lower Cambrian Bastion Formation of North-East Greenland
}

\author{
Ron K. Pickerill and John S. Peel
}

\begin{abstract}
New trace fossil collections are described from Lower Cambrian siliciclastic shallow marine shelf deposits of the Bastion Formation of North-East Greenland, together with a taxonomic re-assessment of previously reported material. The entire assemblage comprises 19 ichnogenera, 25 ichnospecies, as well as two vernacular ichnotaxa. Although no new ichnotaxa are present the material reveals new information on the 3-dimensional structure of two of the contained ichnogenera, namely Plagiogmus Roedel and Psammichnites Torell. The stratigraphic range of a single ichnospecies, Rusophycus latus Webby, is formally extended from the Lower Ordovician to the Lower Cambrian. The assemblage compares favourably with Lower Cambrian ichnocoenoses described from other continents, particularly at the ichnogeneric level. Comparison with similar sequences suggests that the sub-trilobitic Lower Bastion Formation is late Tommotian to early Atdabanian in age, possibly entirely Atdabanian.
\end{abstract}

R. K. P., Department of Geology, University of New Brunswick, Fredericton, N.B., Canada E3B $5 A 3$.

J. S. P., Geological Survey of Greenland, Øster Voldgade 10, DK-1350 Copenhagen $K$, Denmark.

During the last two decades stratigraphic sections of late Precambrian to Early Cambrian age have been the subject of considerable international interest, principally in connection with attempts to define the Precambrian-Cambrian boundary (Cowie \& Brasier, 1989). Trace fossils play an increasing role in these discussions on account of their wide distribution in siliciclastic boundary sequences often lacking in other fossil groups (Crimes, 1987, 1989; Narbonne \& Myrow, 1988). In reviewing the global distribution of trace fossils in strata of this age, Crimes (1987) pointed to the Bastion Formation (Early Cambrian) of North-East Greenland (fig. 1) as one of several sequences which might repay further examination of its trace fossil assemblages.

Cowie \& Adams (1957) first noted the occurrence of trace fossils in the Bastion Formation. They briefly described and figured long narrow grooves (Cowie \& Adams, p. 52, fig. 14, here referred to Plagiogmus) and ridges from the Lower Bastion Formation in the Albert Heim Bjerge area, northern Hudson Land, and recorded Cruziana (p. 176) on Ella $\emptyset$. Subsequently Cowie \& Spencer (1970) briefly mentioned or described 'arthropod scratch marks' (here referred to Monomorphichnus lineatus), Diplichnites, Scolicia (here tenta- tively referred to Psammichnites), Planolites, Phycodes, Skolithos, Arenicolites and 'feather stitch trails', the latter subsequently reported as Treptichnus by Fritz \& Crimes (1985, p. 21), from Ella $\emptyset$. In this later paper Cowie \& Spencer (1970) failed to mention the occurrence of Cruziana in the Bastion Formation although it was recorded from the overlying Ella Island Formation. Cowie \& Spencer (1970, p. 97, pl. 2c) also figured an unidentified 'organic mark' which Crimes et al. (1977, p. $126)$ and, more recently, Crimes \& Jiang (1986, p. 647) tentatively referred to as Taphrhelminthopsis circularis (but see systematic ichnology herein).

Fritz \& Crimes (1985) cited Cowie \& Spencer's (1970) ichnofaunal list but failed to include Arenicolites, Diplichnites and Taphrhelminthopsis. Crimes (1987) repeated the ichnofaunal list but omitted Arenicolites, Taphrhelminthopsis and Treptichnus and included Diplichnites. Crimes (1989) stated that the Lower Bastion Formation contained Monomorphichnus, Phycodes, Planolites, Scolicia, Skolithos and Diplichnites but again omitted Arenicolites, Taphrhelminthopsis and Treptichnus.

Despite the repeated, and somewhat confusing, literature citations noted above, it is apparent that the only primary contribution on the ichnology of the Bastion 


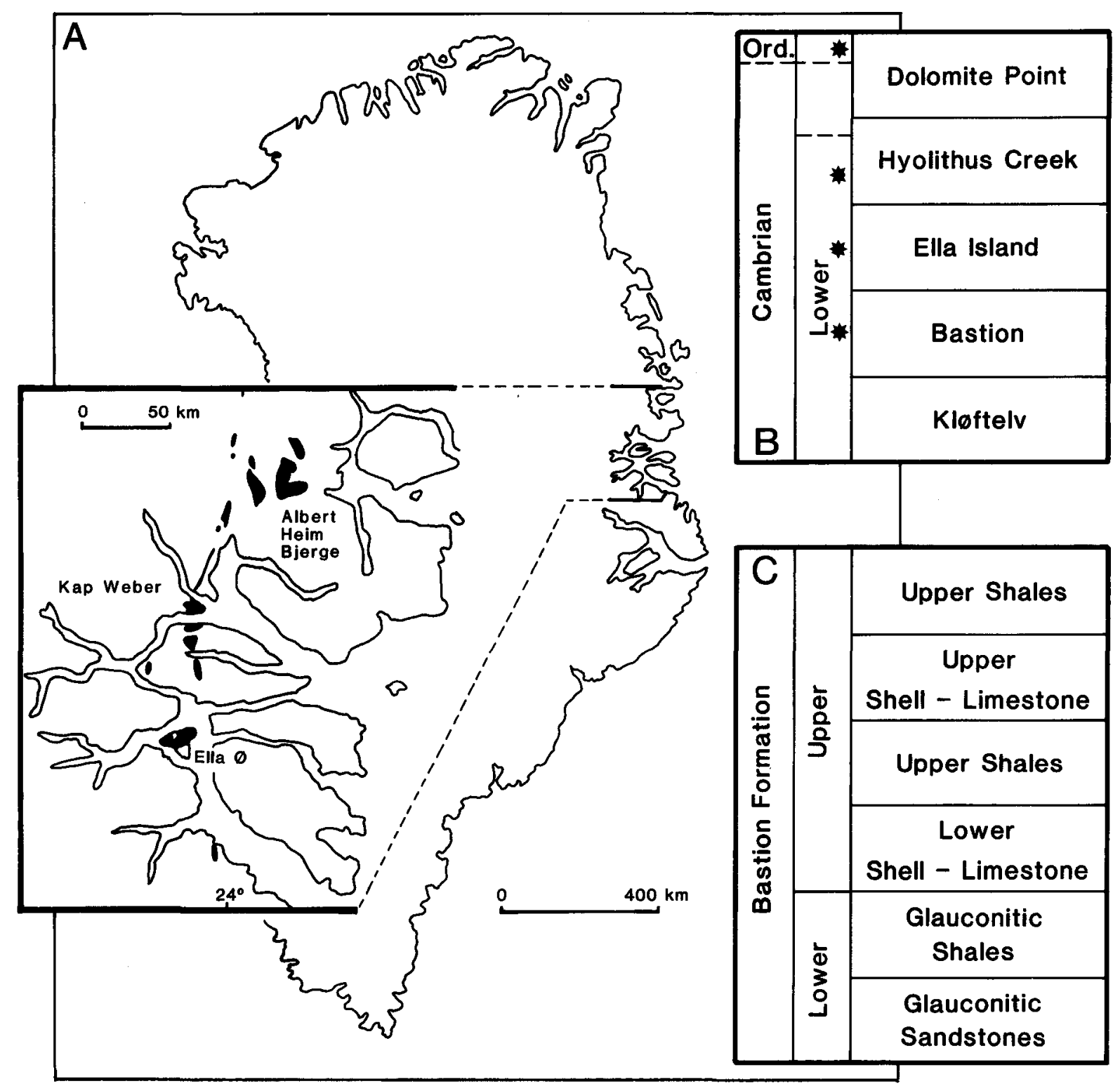

Fig. 1. Trace fossil localities in the Bastion Formation of North-East Greenland. A, general locality map showing the distribution of Cambrian and Ordovician sediments. B, Cambrian stratigraphy; those formations yielding age diagnostic body fossils are starred. C, sub-division of the Bastion Formation proposed by Cowie \& Adams (1957). D-G, sample derivation from Albert Heim Bjerge $(D, E)$, Kap Weber and Ella $\varnothing$; see text.

Formation is that by Cowie \& Spencer (1970). However, trace fossil collections made in 1977 by P. Frykman and in 1988 by J. S. P., under the auspices of the Geological Survey of Greenland (GGU), have increased knowledge of the ichnofaunas within the formation. Interestingly, two of the slabs with trace fossils illustrated by Cowie \& Adams (1957, fig. 14) were collected during 1988; part of one of these is described here (fig. 10b).

The main purpose of this paper is to systematically describe these new collections. In so doing, material described by Cowie \& Spencer (1970), housed in the Geological Museum of the University of Bristol, has been examined for a more detailed taxonomic re-evaluation. The ichnofauna as described is listed in fig. 2.

The study of Cambrian trace fossils from Greenland is still in its infancy, though the contributions of Cowie \& Spencer (1970), Pickerill et al. (1982), Bergström \& Peel (1988), Bergström \& Ineson (1988) and Bryant \& Pickerill (1990) are notable exceptions. This contribu- 

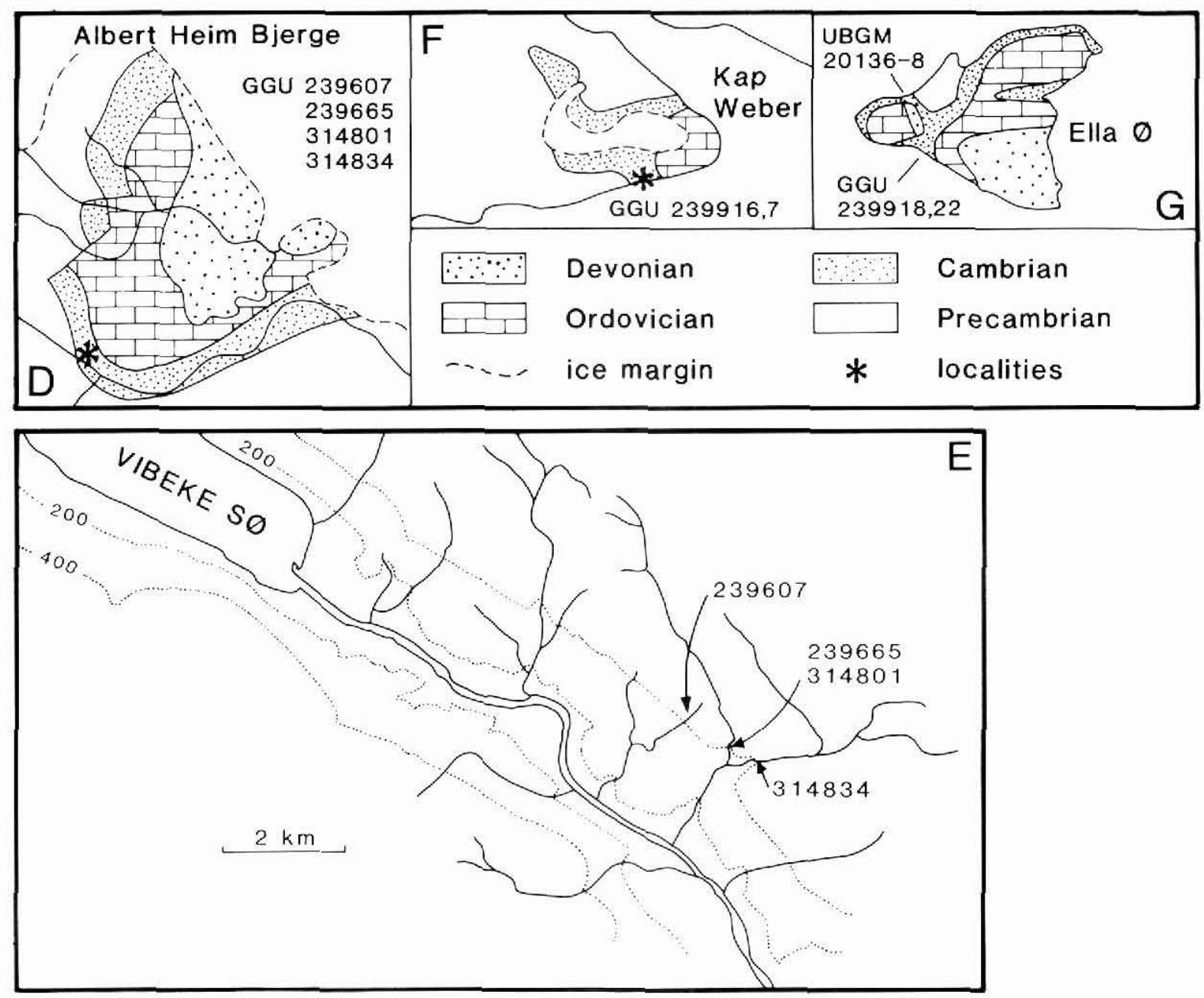

tion therefore provides additional documentation and a more complete record of Cambrian trace fossils from Greenland. Although this article is decidedly taxonomic in nature, the described trace fossils provide additional information on the age of the Bastion Formation, a problem recently highlighted by Crimes (1987). No new ichnogenera or ichnospecies are recognised, but supplementary information is given on the 3-dimensional structure of two of the contained ichnogenera, namely Plagiogmus and Psammichnites. Finally, the stratigraphic range of one of the described ichnospecies, $R u$ sophycus latus Webby, 1983, previously only formally recorded from the Lower Ordovician, is extended to the Lower Cambrian.

\section{Stratigraphy and depositional environment}

The Bastion Formation was named by Poulsen (1930) on the basis of outcrops forming the western promonto- ry of Ella $\varnothing$ (fig. 1). Cowie \& Adams (1957) redefined the formation, referring a suite of quartzites and minor sandstones forming the lower part of Poulsen's formation to the Kløftelv Formation ( $70-80 \mathrm{~m}$ thick). Their restricted Bastion Formation, a sequence of siltstones, shales and subsidiary sandstones and carbonates varying in thickness from $137 \mathrm{~m}$ on Ella $\varnothing$ to $151.5 \mathrm{~m}$ at Albert Heim Bjerge, has been adopted by subsequent workers (cf. Cowie, 1971; Henriksen \& Higgins, 1976; Peel, 1982).

Cowie \& Adams (1957, p. 25) recognised 6 units within the Bastion Formation. A basal unit of Glauconitic Sandstones $(38-47 \mathrm{~m})$ with siltstones and arenaceous shales is overlain by the Glauconitic Shales (6-12.5 $\mathrm{m})$; these 2 units comprise the Lower Bastion Formation. The basal unit of the Upper Bastion Formation is the maroon to green or cream Lower Shell Limestone $(0.5 \mathrm{~m})$ which is composed almost entirely of comminuted shells, with some phosphatic pebbles. The over- 


\begin{tabular}{|c|c|c|c|c|c|c|c|c|c|}
\hline \multirow[b]{2}{*}{ ICHNOTAXA } & \multicolumn{9}{|c|}{ BASTION FORMATION } \\
\hline & \multicolumn{7}{|c|}{ lower } & \multicolumn{2}{|c|}{ upper } \\
\hline $\begin{array}{l}\text { Arenicolites isp. } \\
\text { Bergaueria isp. } \\
\text { Cruziana cf. C. fasciculata } \\
\text { Cruziana problematica } \\
\text { Cruziana isp. type A } \\
\text { Cruziana isp. type B } \\
\text { cf. Curvolithus isp. } \\
\text { Cylindrichnus isp. } \\
\text { Dimorphichnus isp. } \\
\text { Gyrolithes saxonicus } \\
\text { Helminthopsis tenuis } \\
\text { Monomorphichnus lineatus } \\
\text { Neonereites biserialis } \\
\text { Palaeophycus striatus } \\
\text { Palaeophycus tubularis } \\
\text { Phycodes palmatus } \\
\text { Plagiogmus isp. } \\
\text { Psammichnites gigas } \\
\text { Rosselia socialis } \\
\text { Rusophycus dispar } \\
\text { Rusophycus latus } \\
\text { Rusophycus isp. } \\
\text { Skolithos linearis } \\
\text { Taphrhelminthopsis isp. } \\
\text { Teichichnus rectus } \\
\text { epichnial grooves } \\
\text { pit and mound structures }\end{array}$ & $\begin{array}{l}\bullet \\
\bullet \\
\bullet \\
\bullet \\
\bullet \\
\bullet \\
\bullet \\
\bullet \\
\bullet\end{array}$ & $\begin{array}{l}\bullet \\
\bullet\end{array}$ & - & $\begin{array}{l}\bullet \\
\bullet \\
\bullet\end{array}$ & $\begin{array}{l}0 \\
\bullet\end{array}$ & $\begin{array}{l}\bullet \\
\bullet \\
\bullet \\
\bullet\end{array}$ & - & - & $\bullet$ \\
\hline Sandes & 22 & 9 & 2 & 14 & 4 & 7 & 3 & 5 & 2 \\
\hline GGU collection number & 239665 & 314801 & 239607 & 314834 & UBGM & 239918 & 239916 & 239917 & 239922 \\
\hline Location & & & & & & $\varnothing$. & & & A \\
\hline
\end{tabular}

Fig. 2. Summary diagram of ichnotaxa from the Bastion Formation; A. H. B., Albert Heim Bjerge; E. Ø., Ella $\varnothing ;$ K. W., Kap Weber; A, Antiklinalbugt, Ella $\varnothing$ (see text for details). Solid circles indicate presence of an ichnotaxon within an individual collection. 
lying Lower Shales $(32-35.5 \mathrm{~m})$ are glauconitic and micaceous and contain bands of limestone, arenaceous limestone or mudstone. The Upper Shell Limestone $(2.5-10 \mathrm{~m})$ consists of bands rich in fossil debris interbedded with shales and siltstones. The Upper Shales $(48-56 \mathrm{~m})$ are mainly arenaceous shales with massive mudstone beds which become more common towards the top of the formation.

Henrik Tirsgaard (Geological Survey of Greenland) briefly examined the Kløftelv and Bastion Formations at Albert Heim Bjerge and writes:

\section{Kløftelv Formation}

The quartzite units of the Kløftelv Formation are dominated by $0.2-1 \mathrm{~m}$ thick sets of large-scale planar cross-bedding, containing reactivation surfaces and sometimes showing herring-bone cross-stratification. Trough cross-stratification and ripple cross-lamination are subordinate structures. No distinct vertical sequences are apparent within the quartzite units. A tidally influenced nearshore marine origin is most likely but the poor preservation of sedimentary structures precludes a more detailed interpretation. The alternation of the 3 major quartzitic units with thin sandstone units is probably a result of minor transgressions, each commencing at the top of a quartzite unit.

\section{Bastion Formation}

The contact between the Kløftelv Formation and the overlying Bastion Formation represents a major transgression accompanied by the formation of a conglomerate containing glauconite and phosphate nodules. A similar conglomerate is found at about $20 \mathrm{~m}$ above the base of the Lower Bastion Formation which consists of heterolithic sandstone and siltstone layers $(1-20 \mathrm{~cm}$ thick) interbedded with beds of sandstone $(1-25 \mathrm{~cm})$. The sandstone beds have sharp bases and internally contain parallel to hummocky cross-stratification. Ripple cross-lamination commonly occurs in the upper part of the sandstone beds. No vertical evolution is apparent within the lower $20 \mathrm{~m}$ of the Lower Bastion Formation.

Deposition of the Lower Bastion Formation occurred below fair weather wave base, in the marine offshoretransition zone (sensu Elliot, 1986). The alternation of sandstones and heterolites indicates sedimentation during alternating energy conditions, with the sandstones being deposited during storm events and the fine grained sediment during fair weather.

The second transgression, initiated some $20 \mathrm{~m}$ above the base of the Lower Bastion Formation, resulted in a decrease in the sandstone content and a marked de- crease in the abundance of biogenic structures. Sandstone content subsequently increases slightly upwards towards the top of the Lower Bastion Formation, indicating gradual shoaling. Sedimentation, however, remained within the offshore-transition zone.

A third transgression, manifested by the Lower Shell Limestone, marks the contact between the Lower Bastion Formation and the Upper Bastion Formation. The latter consists mainly of shales with thin beds of limestones and mudstones. Deposition within the Upper Bastion Formation occurred mainly from suspension, well below wave base in an offshore shelf environment.

\section{Repository and material}

Collection numbers for all material collected by the Geological Survey of Greenland are prefixed by GGU. Individual specimens or slabs within single collections are consecutively numbered according to the order in which they were examined in the laboratory (e.g. GGU 239665-1, GGU 239665-2). Figured specimens also bear a number prefixed by MGUH and are housed in the Geological Museum, University of Copenhagen. Material described by Cowie \& Spencer (1970) is housed in the Geological Museum, University of Bristol, and is prefixed by UBGM. This latter material was collected from Bastionbugt on the northern side of Ella $\varnothing$ (fig. 1A,F; see Cowie \& Spencer, 1970, p. 92). The material from 1977 and 1988 comprises 64 samples (single specimens or slabs of varying dimensions) from 8 collections made from Albert Heim Bjerge, Kap Weber and Ella $\varnothing$, as located in fig. 1 and discussed below.

GGU collections 239665 and 314801 . Talus material adjacent to the lowermost few metres of the Lower Bastion Formation at Albert Heim Bjerge (fig. 1D,E). Collection GGU 239665 by P. Frykman, 1977; 22 samples; collection GGU 314801 by J. S. Peel and M. P. Smith, $1988 ; 9$ samples.

$G G U$ collection 239607 . Talus material from the Lower Bastion Formation at Albert Heim Bjerge collected by P. Frykman, 1977; 2 samples (fig. 1D,E).

GGU collection 314834 . Talus material adjacent to the lowermost few metres of the Lower Bastion Formation at Albert Heim Bjerge collected by J. S. Peel and M. P. Smith, 1988; 14 samples (fig. 1D,E).

GGU collection 239916. In situ material from the Lower Bastion Formation at Kap Weber, collected by P. Frykman, 1977; 3 samples (fig. 1E,F). 
GGU collection 239918. Talus material from the Lower Bastion Formation at Antiklinalbugt, west side of anticline, Ella $\emptyset$, collected by P. Frykman, 1977; 7 samples (fig. 1F,G).

GGU collection 239917. In situ material from the Upper Bastion Formation adjacent to the contact with the overlying Ella Island Formation at Kap Weber, collected by P. Frykman, 1977; 5 samples (fig. 1F).

GGU collection 239922. In situ material from the Upper Bastion Formation at Antiklinalbugt, east side of anticline, Ella $\emptyset$, collected by P. Frykman, 1977; 2 samples (fig. 1F,G).

\section{Systematic ichnology}

Following conventional practise in palichnology the ichnotaxa are described alphabetically for ease of reference; vernacular ichnotaxa are briefly described for completeness following the formally documented forms. Preservational terminology follows that adopted by Seilacher (1964), Webby (1969), Martinsson (1970) and Simpson (1975), as summarised in Häntzschel (1975) and Ekdale et al. (1984). The material listed for each ichnotaxon represents those specimens or slabs from a collection where confident or reasonably confident identification was made. Some slabs contain only non-descript or poorly preserved material insufficient for identification even at the ichnogeneric level and therefore this material is excluded from the following descriptions. Most specimens are preserved in finegrained to medium-grained sandstones; this grain size inhibits both preservation and the observation of fine details; figured specimens (apart from those housed in the Geological Museum, University of Bristol) were coated with sublimate of ammonium chloride.

Ichnogenus Arenicolites Salter, 1857

Arenicolites isp.

Figs $3 a, b, 4 b, 5 a$

Material. Twenty-four specimens from GGU collections 239665-20, 239665-21, 239916-1, 314834-18, 314801-1.

Description. Specimens occur as either rare vertical Uplane (sensu Osgood, 1970) sections (figs 3a,b) or more typically as paired circular openings usually preserved in concave epirelief (fig. 4b) but also in convex hyporelief (fig. 5a). In bedding surface sections, the tubes are 8 to $21 \mathrm{~mm}$ apart, typically 2 to $4 \mathrm{~mm}$ in diameter; diameter is constant for a single pair, and the sediment between the tubes is undisturbed. In vertical U-plane section the tubes are vertical to sub-vertical, thinly lined or unlined. The fill is finer-grained (muddy sandstone) than the enclosing sandstone matrix. The restricted thickness of the slabs containing the traces normally precludes observation of the basal U-bend (e.g. fig. 3b) and hence the depth of penetration of the material, although the undisturbed nature of the material between the tubes can clearly be ascertained.

Remarks. Cowie \& Spencer (1970) briefly noted the occurrence of Arenicolites, with individual tubes 10 to $15 \mathrm{~mm}$ apart, from the Bastion Formation of Ella $\emptyset$, but no additional information was given. Arenicolites is a commonly occurring ichnotaxon in the Lower Bastion Formation of Albert Heim Bjerge (J. S. P., field observations). The limited material described here is therefore no reflection on its actual abundance within the Lower Bastion Formation.

Ichnospecific identification of Arenicolites requires knowledge of both bedding surface and U-plane expressions and, therefore, the material described here is only identified at the ichnogeneric level. Bedding plane expressions are assigned to Arenicolites because of the paired tube association and lack of sediment disturbance between the tubes. Several vertical U-plane sections resemble $A$. statheri Bather, 1925 in that this ichnospecies possesses lined vertical to sub-vertical tubes, but this ichnospecies is considerably larger and may possess funnel-shaped openings (Fürsich, 1974). Incomplete 3-dimensional knowledge of the majority of additional ichnospecies of Arenicolites, such as A. compressus (Sowerby, 1829), A. subcompressus (Eichwald, 1860), A. carbonaria (Binney, 1852), A. curvatus Goldring, 1962, and A. naraensis Badve \& Ghare, 1978 suggests that taxonomic re-evaluation of the ichnotaxon is necessary, particularly at the ichnospecific level.

Ichnogenus Bergaueria Prantl, 1945

Bergaueria isp.

Figs $3 \mathrm{c}, \mathrm{d}$

Material. One specimen from GGU collection 239665-15.

Fig. 3. a, b, U-plane cross-sectional views of Arenicolites isp.; a is MGUH 19.654 from GGU collection $239916-1$ and b is MGUH 19.655 from GGU collection 239665-21. c, d, basal (c) and lateral (inverse) view (d) of Bergaueria isp.; MGUH 19.656 from GGU collection 239665-15. Note the relatively steep walls (arrowed) in d. 


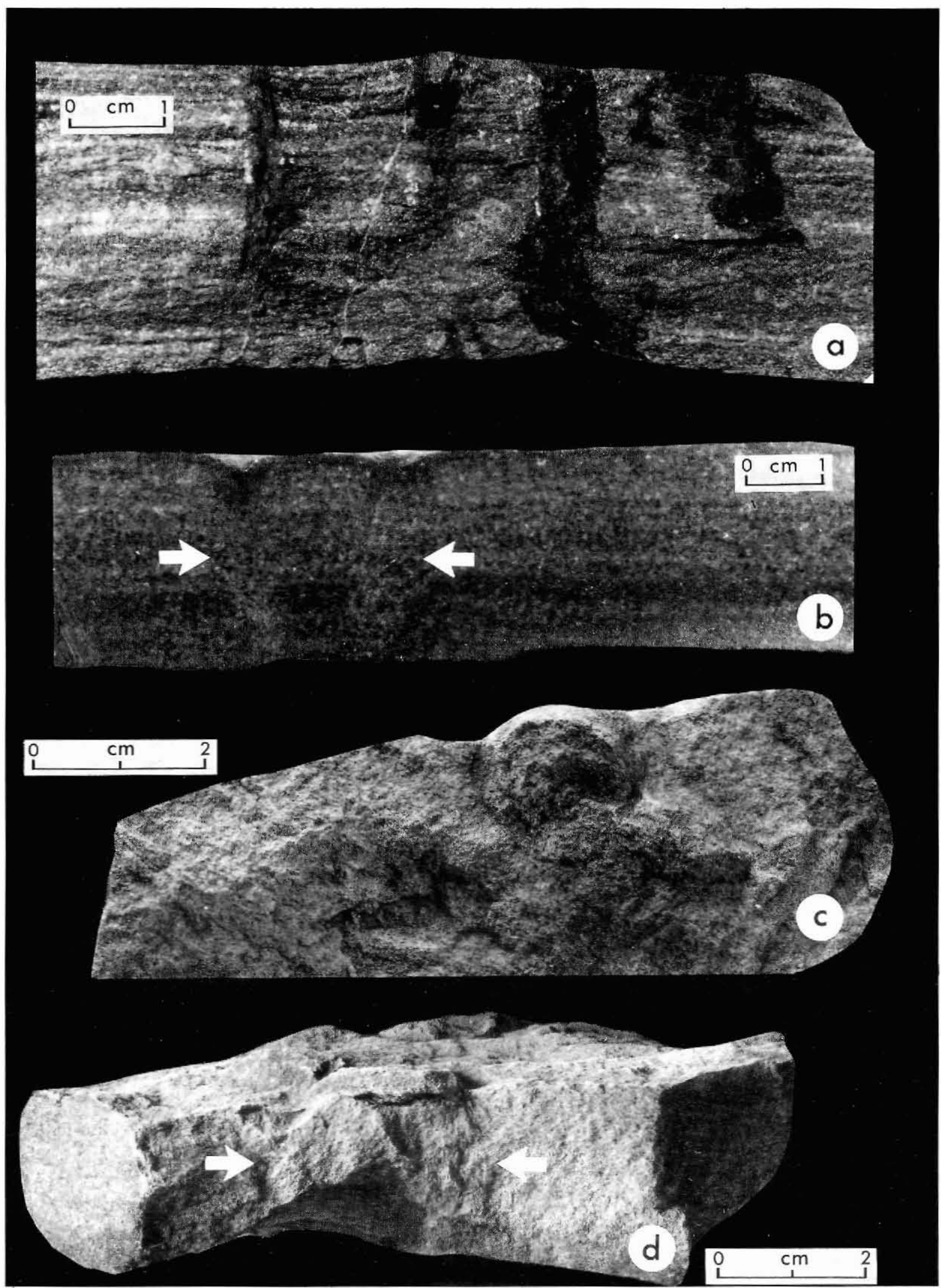


Description. The specimen consists of an irregular, somewhat compactionally flattened and erosionally truncated, thinly walled hemispherical structure preserved in convex hyporelief and endorelief, 1.6 to 1.9 $\mathrm{cm}$ in diameter and extending vertically for at least 2.3 $\mathrm{cm}$. The external walls are sharp, steeply inclined and unornamented. The basal surface is irregular and possesses rudimentary concentric ornamentation. Burrow fill is structureless and of similar grain size to the host rock.

Remarks. Based on the criteria recently comprehensively reviewed by Pemberton et al. (1988) for distinguishing single-entrance, plug-shaped ichnogenera, the specimen can best be regarded as a truncated and irregularly eroded Bergaueria. The incomplete and poor preservation of the single specimen negates ichnospecific assignment, as the four ichnospecies recognised by Pemberton et al. (1988) are primarily based on detailed analysis of the nature of the distal terminations and the wall characteristics (here unobserved). B. perata Prantl, 1945 and B. hemispherica Crimes, Legg, Marcos \& Arboleya, 1977 would be favourable candidates for comparison, however, should additional material become available. These ichnospecies are both thinly walled and commonly possess concentric ornamentation (Pemberton et al., 1988; Pickerill, 1989), particularly B. perata.

\section{Ichnogenus Cruziana d'Orbigny, 1842}

Remarks. Seilacher (1970) united under Cruziana both cruzianaeform and rusophyciform arthropod burrows and, although some authors have subsequently adopted this scheme, most have preferred to retain Cruziana d'Orbigny, 1842 and Rusophycus Hall, 1852 as distinctive and separate ichnogenera (for references see Crimes et al., 1977; Bromley \& Asgaard, 1979). This is more in accordance with CTFN, Article 40 (Code for Trace Fossil Nomenclature, Sarjeant, 1979) and ICZN, Article 231 (International Code of Zoological Nomenclature, 3rd Edition, 1985), and therefore we adopt this latter scheme and describe the ichnotaxa separately.
Cruziana cf. C. fasciculata Seilacher, 1970

Figs 4d, 12c,d

Material. One specimen from GGU collection 239917-3.

Description. The specimen consists of a short segment of a generally poorly but variably preserved cruzianid, preserved in convex hyporelief on a sandstone sole, which essentially exhibits, and obviously formed subsequent to, Rusophycus dispar Linnarsson, 1869 (see fig. 12c). The trace is relatively shallowly impressed and bilobed, with each lobe possessing fine and relatively narrow scratches; where preservation is clear, these are arranged in bundles of four to six and are oriented at angles of 35 to 60 degrees with respect to the poorly developed median furrow. Scratches within individual bundles do not intersect, are straight to slightly sinuous and are subequal in length. Specimen width is $2.7 \mathrm{~cm}$ and maximum exposed length is $2.8 \mathrm{~cm}$.

Remarks. In view of the fact that just a single and generally poorly preserved specimen is present, the identification as Cruziana cf. C. fasciculata is only tentative. This ichnospecies is an important member of the 'fasciculata group' of Seilacher (1970), members of which are all of Early Cambrian age, and are characterised by cruzianids possessing bundles of four to six subequal scratches that are relatively finely impressed and form obtuse angles to the median furrow. Crimes $e t$ al. $(1977$, p. 99, pl. 1a) figured a similar but much wider example than that described here from the Lower Cambrian of Spain and Crimes \& Anderson (1985, p. 317) described a $2.5 \mathrm{~cm}$ wide specimen from the Lower Cambrian of south-eastern Newfoundland.

\section{Cruziana problematica (Schindewolf, 1921) Figs 5a,b}

Material. Eighteen specimens from GGU collections 314801-1, 314801-2, 314801-3, 239665-3, 239665-7, 239916-3, 239918-7, ?314834-12.

Description. Specimens are variably preserved in convex hyporelief on sandstone soles and consist of short $(2.5 \mathrm{~cm})$ to long $(20 \mathrm{~cm}), 4$ to $7 \mathrm{~mm}$ wide, essentially

Fig. 4. a, Cruziana isp. type A preserved in convex hyporelief on sandstone sole; MGUH 19.657 from GGU collection $314834-13$. b, Arenicolites isp. on upper bedding surface preserved as paired circular openings; MGUH 19.658 from GGU collection 239665-20. c, Cruziana isp. type B preserved in convex hyporelief on sandstone sole; MGUH 19.659 from GGU collection 239922-1. Note also the basal portion of Teichichnus rectus (arrowed) which is shown in cross-section in fig. 14a. d, Cruziana cf. C. fasciculata preserved in convex hyporelief on sandstone sole; MGUH 19.660 from GGU collection 239917-3. 


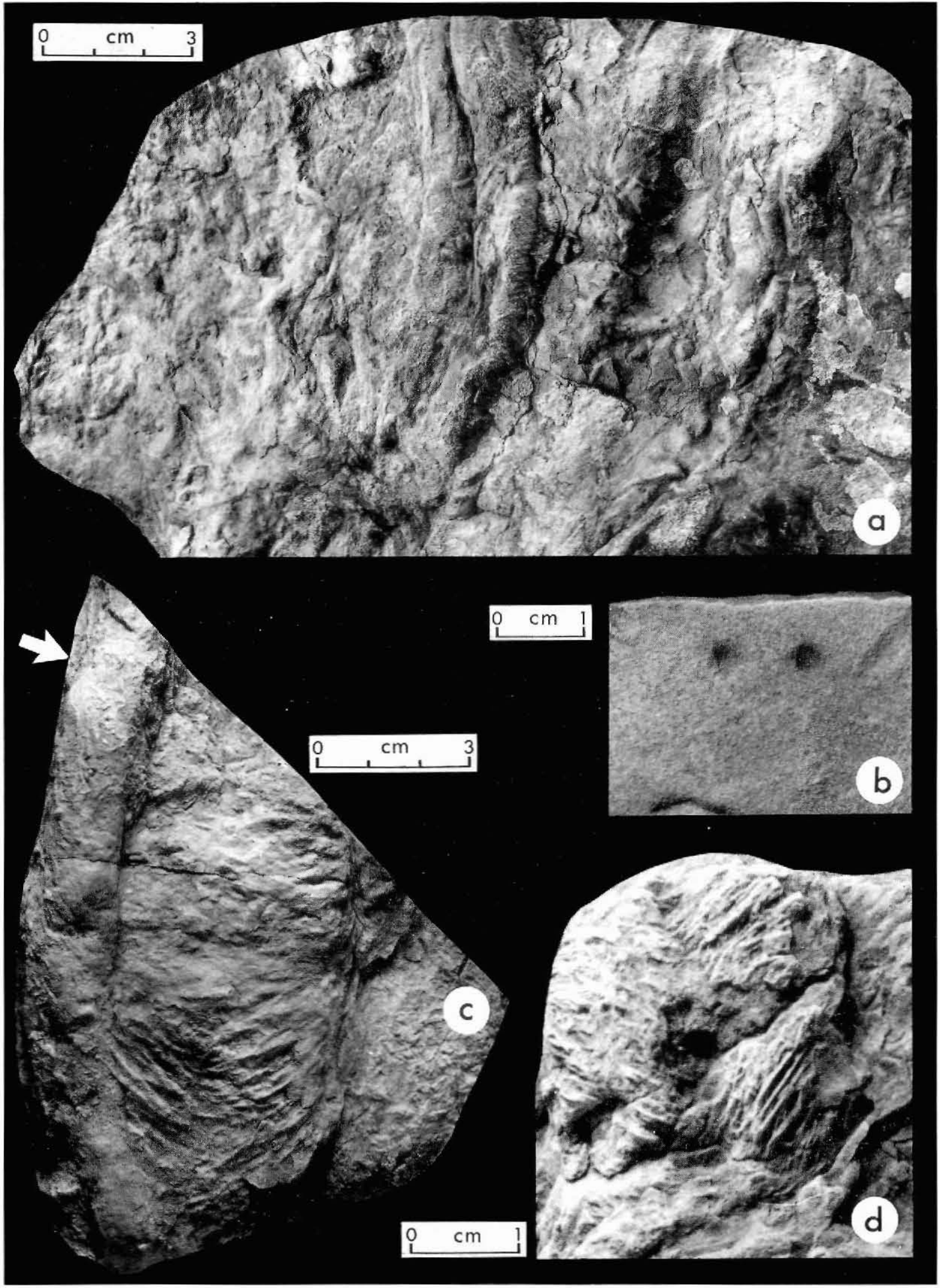


bilobed, horizontal and symmetrical burrows that may follow a straight, curved or flexuous course. Individual burrows may or may not intersect. Specimens possess different characteristics depending on depth of impression. Fig. 5b, for example, exhibits two specimens. The more deeply impressed example is relatively wide with individual lobes possessing transverse or highly obtuse, irregularly spaced $(0.5$ to $2 \mathrm{~mm})$ sediment pods that extend from the very narrow axial furrow to the margins of the lobes. The associated narrower and less deeply impressed example possesses lobes that are narrower with respect to the wider axial furrow and transverse ornament that is only feebly developed. Fig. 5a (upper left to central right) exhibits a third variation where a single specimen is relatively deeply impressed at one end and therefore exhibits the typical bilobed appearance, each lobe possessing very delicate, transverse and unevenly spaced scratches. For the majority of its course, however, this specimen is very shallowly impressed and assumes the appearance of a simple and smooth, unilobed, horizontal burrow. Some specimens extend upward as endichnial burrows into the overlying sandstone at their terminations. Rare examples exhibit slightly enlarged and more deeply impressed bilobed expansions along their length.

Remarks. These morphologically variable traces, a result of preservational conditions, burrowing level, interface relationships etc., clearly represent preservational variants of a single ichnotaxon, but this is not unusual in ichnology (for example, see Seilacher, 1970). We refer the material to Cruziana rather than Isopodichnus Bornemann, 1889 following the reasoning of Bromley \& Asgaard (1979) and more recently Romano \& Whyte (1987). As noted by Trewin (1976), distinction between different ichnospecies of small and narrow Cruziana (= Isopodichnus of many previous authors) is difficult without large numbers of well-preserved specimens that illustrate the whole range of burrow morphology. However, although the material described here is limited to eighteen specimens we regard it as conspecific with $C$. problematica, an ichnospecies characterised by transverse and unevenly spaced scratches and typically less than $7 \mathrm{~mm}$ in width. Bromley \& Asgaard (1979) have described and illustrated C. problematica exhibiting a similar range in morphological variation to that described herein.

\section{Cruziana isp. type A}

Fig. 4a

Material. Two specimens from GGU collection 314834-13.

Description. Both specimens occur as convex hyporeliefs on a silty sandstone sole and are variably and poorly preserved. The figured specimen is a curved, $12.5 \mathrm{~cm}$ long, 2.9 to $3.9 \mathrm{~cm}$ wide bilobed trace. It exhibits moderately developed endopodal lobes and an axial furrow at the deeper impressed $(1.2 \mathrm{~cm})$ extremity, and poorly developed equivalents where it merges with the more typical stratification level of the sandstone sole. Portions of the endopodal lobes, particularly towards their outer margins, possess faint and relatively dense (one per $\mathrm{mm}$ ), typically transverse scratches that may be oriented, however, up to 70 to 80 degrees with respect to the axial furrows. The scratches are unifid and only finely impressed. The second specimen is less well preserved, $18 \mathrm{~cm}$ in length and $2.3 \mathrm{~cm}$ in width, with similarly developed but poorly preserved scratches.

Cruziana isp. type B

Fig. $4 \mathrm{c}$

Material. One specimen from GGU collection 239922-1.

Description. Preserved in convex hyporelief on a sandstone sole also containing Teichichnus rectus Seilacher, 1955 (fig. 4c), the single specimen is at least $11.4 \mathrm{~cm}$ long, $4.8 \mathrm{~cm}$ wide and $1.2 \mathrm{~cm}$ deep. Preservation is generally poor but variable; endopodal lobes are only weakly developed towards the posterior end of the specimen where they possess relatively deeply impressed scratches. The remainder of the specimen is virtually unilobate with no axial furrow development and sporadically and irregularly distributed scratches (fig. 4c). The scratches, where preserved, are generally coarse, sharp and clearly defined, bifid, or at least associated in pairs, and only rarely intersect. They are oriented at an average angle of 60 to 70 degrees to the mid-line of the trace; they curve to assume a more acute angle towards the mid-line and a less acute angle near the external margins.

Fig. 5. a, b, Cruziana problematica preserved in convex hyporelief on sandstone sole; larger specimen in b is MGUH 19.661 from GGU collection 314801-1. Note the variable morphology depending on depth of impression; $b$ is an enlarged view of the specimens exhibited at mid-right in a; note also several examples of Arenicolites isp. (two of which are arrowed) in a, which represent MGUH 19.662 and MGUH 19.663 from GGU collection 314801-1. 


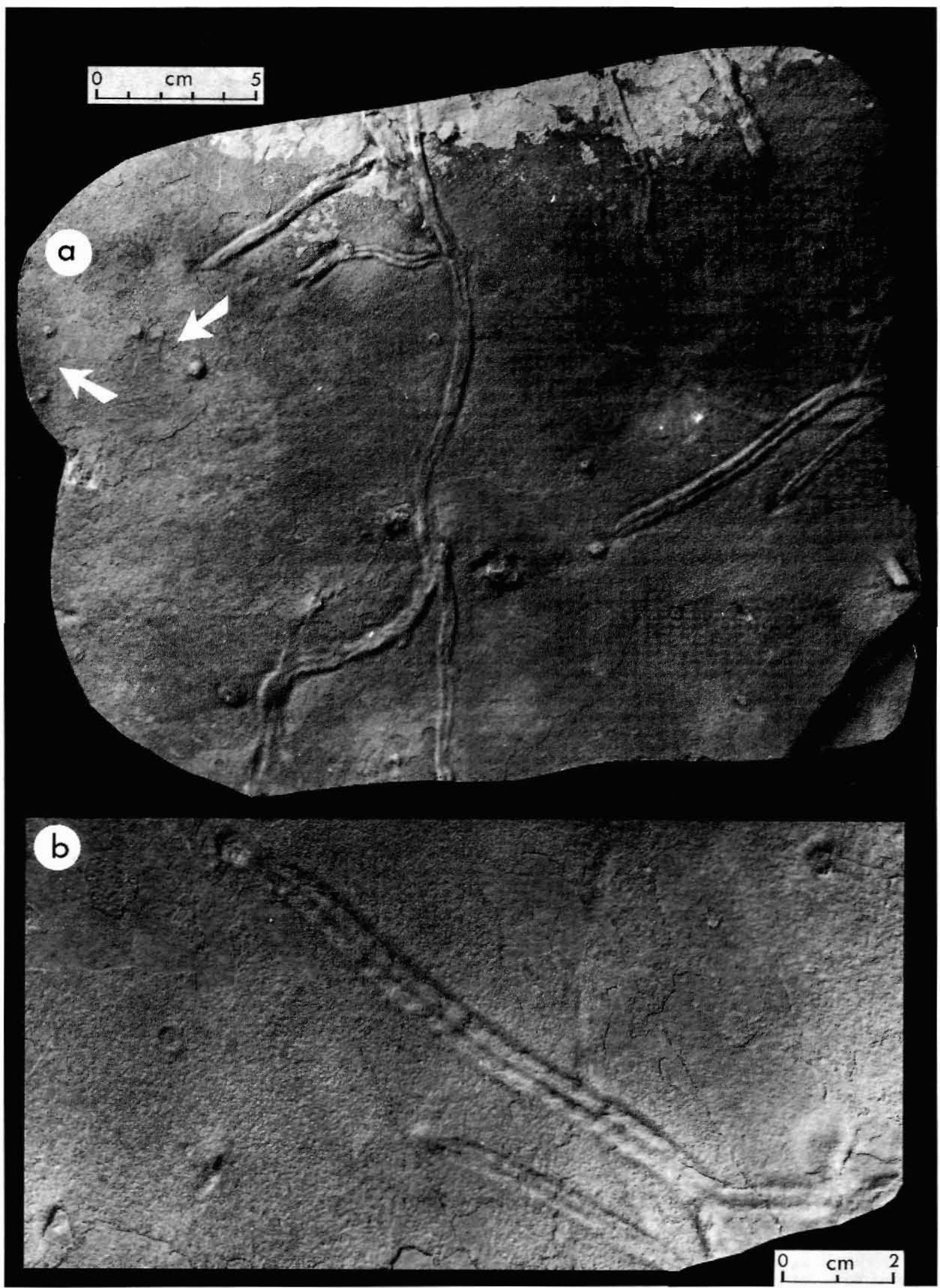


Remarks. Crimes $(1987$, p. 105) noted that the majority of Lower Cambrian Cruziana have only been previously identified at the ichnogeneric level because of the difficulty in deciphering the claw patterns in what is commonly poorly preserved material. This is certainly true for the material described here, where preservation is typically poor and the limited number of specimens does not permit observation of the complete range of morphological variation necessary for valid ichnospecific assignment. Nevertheless, it is still clear that two additional and different ichnospecies, herein referred to as Cruziana ispp. types A and B, are present in the Bastion Formation collections. We are unfamiliar with any comparable analogues to Cruziana isp. A. Cruziana isp. B, at its posterior extremity, somewhat resembles Cruziana dispar (Linnarsson, 1869), a distinctive Lower Cambrian ichnospecies more recently discussed and described by Seilacher (1970) and, particularly, Bergström \& Peel (1988). However, most of the specimen is essentially unilobate, similar to C. barriosi Baldwin, 1977, and $C$. dispar is decidedly bilobate; this, however, may simply be a reflection of preservational variability.

\section{Ichnogenus Curvolithus Fritsch, 1908}

cf. Curvolithus isp.

Fig. 6

Material. One specimen from GGU collection 314834-21.

Description. The specimen is poorly preserved on a pale green sandstone bedding surface and consists of an incomplete, curved, $10 \mathrm{~cm}$ long, $1.6 \mathrm{~cm}$ wide trilobed trace. Each lobe, two marginal and one axial, is gently convex, smooth and unornamented, approximately but uniformly $3 \mathrm{~mm}$ wide and raised slightly less than $1 \mathrm{~mm}$. The lobes separate $3.5 \mathrm{~mm}$ wide, smooth and unornamented, flat surfaces which are at the same level as the plane of stratification.

Remarks. Fritsch (1908) introduced Curvolithus for trilobed burrows from the Ordovician of Czechoslovakia. Heinberg $(1970,1973)$ demonstrated the considerable morphological variation exhibited by the ichnogenus, which prompted Fillion \& Pickerill (1990) to regard it as a candidate for taxonomic revision. Heinberg (1973) and Heinberg \& Birkelund (1984) suggested the most likely producers to have been molluscs burrowing within the sediment, though more recently Lockley et al. (1987) suggested polychaetes, nermerteans and holothurians as possible candidates.

It is unknown whether the specimen is preserved on an upper or lower bedding plane surface but we tentatively identify it as Curvolithus based on its trilobed morphology. Other potential alternatives include $\mathrm{Scol}$ icia de Quatrefages, 1849 and Subphyllochorda Gotzinger \& Becker, 1932, both of which also exhibit a wide range of morphology depending upon style and level of preservation.

\section{Ichnogenus Cylindrichnus Toots in Howard, 1966}

Cylindrichnus isp.

Fig. $7 \mathrm{a}$

Material. Two specimens from GGU collection 239665-14.

Description. Specimens occur as concentrically lined cylindrical structures preserved in concave epirelief on the upper surface of a sandstone bed. The concentric linings consist of alternating light and dark, less than $1 \mathrm{~mm}$ thick, sandstone and muddy sandstone layers. Burrow diameters are $5.1 \mathrm{~mm}$ and $4.2 \mathrm{~mm}$; length unobserved, course presumably vertical. Burrow walls are sharp and clearly defined; fill is darker in colour but generally of similar grain size to the enclosing sandstone.

Remarks. As the specimens were not observed longitudinally it is unknown whether they represent $C$. concentricus Toots in Howard, 1966, C. pustulosus Frey \& Bromley, 1985 or $C$. errans D'Alessandro \& Bromley, 1986. C. concentricus is smooth-walled, whereas $C$. pustulosus possesses inconsistently spaced ridges and irregular large knobs on the outer wall. $C$. errans possesses lateral, randomly orientated, limited displacements of the causative shaft, producing vertical spreiten. Preservation in concave epirelief demonstrates that the structures do not taper downwards into a funnel-shape, such as in the ichnogenera Rosselia Dahmer, 1937 or Monocraterion Torell, 1870, thus enabling recognition at least at the ichnogeneric level. More complete descriptions and discussions of the ichnogenus are available in Fürsich (1974), Howard \& Frey (1984), Frey \& Bromley (1985), Frey \& Howard (1985) and D'Alessandro \& Bromley (1986).

\section{Ichnogenus Dimorphichnus Seilacher, 1955}

Dimorphichnus isp.

Fig. $7 \mathrm{~b}$

Material. One specimen from GGU collection 314801-4. 


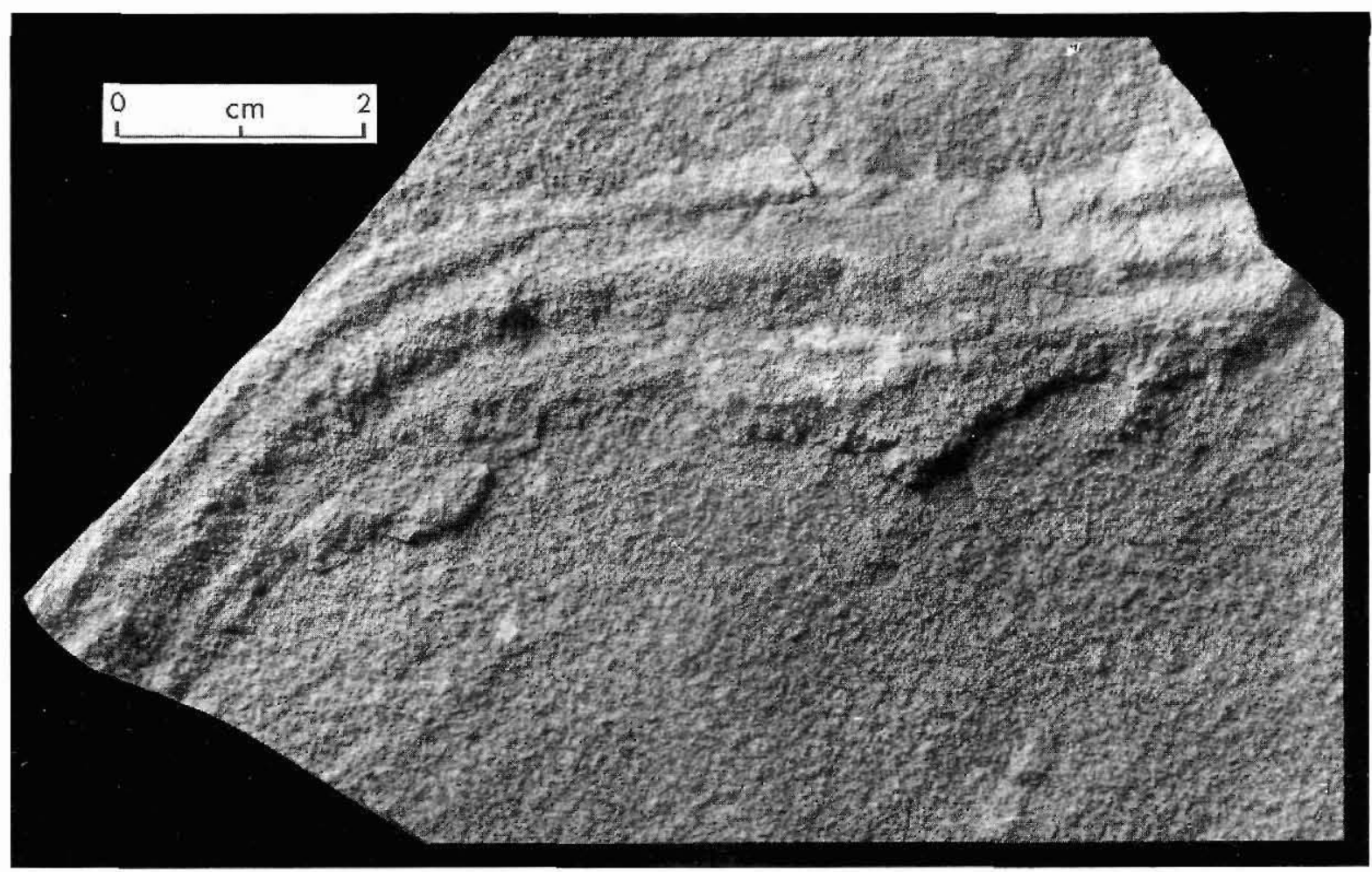

Fig. 6. Bedding plane view of cf. Curvolithus isp., MGUH 19.664 from GGU collection 314834-21.

Description. The specimen consists of a paired and parallel series of imprints preserved in convex hyporelief on a sandstone sole. One series of imprints is composed of three, possibly four, impressions, each 4 to $5 \mathrm{~mm}$ in length and $1 \mathrm{~mm}$ wide. These imprints are straight to slightly arcuate and are separated from the second series by $6 \mathrm{~mm}$ of undisturbed sediment. The second series comprises four, possibly five, straight imprints, each 2 to $3 \mathrm{~mm}$ in length and $1 \mathrm{~mm}$ in width. Individual imprints are featureless and are oriented normal to the track axis.

Remarks. Seilacher (1955) crected the ichnogenus Dimorphichnus for arthropod-produced dimorphic imprints of this configuration, erecting $D$. obliquus Seilacher, 1955 as the type. Although the ichnogenus still remains monospecific, the majority of authors have preferred to recognise Dimorphichnus at the ichnogeneric level (e.g. Crimes, 1970; Baldwin, 1977; Legg, 1985), presumably a reflection of its inherent morphological variability. The single and generally poorly preserved specimen from the Bastion Formation does not resemble $D$. obliquus. This ichnospecies is characterised by imprints of dot and sigmoidal shape but, following Legg (1985), the asymmetry of the imprints is the diagnostic feature allowing identification at the ichnogeneric level.
Fillion \& Pickerill (1990) have recently discussed in detail the distinction of Dimorphichnus from the morphologically similar tracks Diplichnites Dawson, 1873 and Petalichnus Miller, 1880.

Ichnogenus Gyrolithes de Saporta, 1884

Gyrolithes saxonicus (Häntzschel, 1934) Fig. $7 \mathrm{c}$

Material. Three specimens from GGU collections 239665-6, 239665-17, 239918-4.

Description. The specimens, preserved in endorelief within fine-grained sandstones, are poorly preserved, incomplete and much compacted. Each consists of incomplete portions of dextrally coiled vertical burrows, with upward spirals decreasing in diameter. Coiling is regular and successive whorls are in contact but do not intersect. Burrows possess smooth surfaces, are oval in cross-section (probably a result of compaction) and have a maximum and apparently uniform diameter of approximately $5 \mathrm{~mm}$. Maximum interpolated whorl diameter is approximately $5 \mathrm{~cm}$.

Remarks. Though superficially resembling the ichnogenus Fuersichnus Bromley \& Asgaard, 1979, which ex- 
hibits horizontal, retrusive, curved burrow systems, the material described here is decidedly vertical and is therefore included within Gyrolithes de Saporta, 1884. $G$. saxonicus (Häntzschel, 1934) differs from the type ichnospecies $G$. davreuxi de Saporta, 1884, as described by Bromley \& Frey (1974), by its smaller diameter, smooth external surface and regularity of coiling. $G$. marylandicus (Mansfield, 1927) and G. bularti Macsotay, 1967 are considerably larger and exhibit more open coiling. G. polonicus Fedonkin, 1980 is characterised by an incomplete circular whorl inferred to represent one turn of a coil about a vertical axis (Crimes \& Anderson, 1985) and clearly differs from the material described here. Additional ichnospecies of Gyrolithes, as erected by de Saporta (1884), together with the junior synonym Xenohelix Mansfield, 1927 and its various ichnospecies (see Häntzschel, 1934, 1975; Macsotay, 1967) are no longer in general use. Daemonhelix Barbour, 1892 and Dinocochlea Woodward, 1922 are also probably junior synonyms of Gyrolithes, but re-examination of types will be necessary to confirm this. In view of the considerable degree of morphological variability of even the type material (Bromley \& Frey, 1974), Gyrolithes and its synonyms are serious candidates for taxonomic re-evaluation. Until then, however, the material described here is assigned to $G$. saxonicus. More complete discussions on the nature and affinities of Gyrolithes are given in Gernant (1972), Bromley \& Frey (1974) and Powell (1977).

\section{Ichnogenus Helminthopsis Heer, 1877}

\section{Helminthopsis tenuis Książkiewicz, 1968}

Fig. 7d

Material. Several specimens from GGU collections $314834-5$ and 314834-6. Note that these two numbered collections are part of the same but broken slab.

Description. Thin, slender burrows preserved in convex hyporelief on a sandstone sole, uniformly 0.8 to $1 \mathrm{~mm}$ in diameter and up to a maximum length of $5 \mathrm{~cm}$. Individual burrows loop or meander irregularly, some meanders high and narrow, others low and broad. Single burrows never display self level-crossing but may be intersected by alternate systems. Burrow surfaces are smooth; burrow fill is similar in grain size to enclosing sediment.

Remarks. The specimens somewhat resemble Helminthoidichnites Fitch, 1850, placed into synonymy with Gordia Emmons, 1844 by Häntzschel (1975, p. W64) but recently resurrected by Hofmann \& Patel (1989). They differ from this ichnotaxon by the presence of common meandering, a feature absent in the types displayed by Fitch (1850). They also resemble Gordia, but this ichnogenus is characterised by strings that wind but do not meander, with a marked tendency to intersection within single systems (Fillion \& Pickerill, 1990). An exception to this is $G$. meandria Jiang in Jiang et al., 1982, as also figured by Crimes \& Jiang (1986, p. 646, fig. 4h), but this ichnotaxon exhibits large guided meandering strings that do not cross-cut; the ichnotaxon should best be assigned to an alternative ichnogenus. As such, we consider the material here conspecific with $H$. tenuis and do not concur with Häntzschel (1975, p. W70) to include this ichnospecies as a junior synonym of Gordia. More complete discussions and descriptions of $H$. tenuis are given in Książkiewicz $(1968,1977)$.

\section{Ichnogenus Monomorphichnus Crimes, 1970}

\section{Monomorphichnus lineatus Crimes, Legg, Marcos} \& Arboleya, 1977

Figs $8 \mathrm{a}, \mathrm{b}$

Material. Two specimens from the collections made by Cowie \& Spencer (1970); UBGM 20136 and UBGM 20137; both figured.

Description. Specimen UBGM 20136 comprises a set of seven slightly arcuate ridges preserved in convex hyporelief on a sandstone sole. The ridges are of unequal length (4 to $14 \mathrm{~mm}$ ), approximately $1 \mathrm{~mm}$ in width (average) and are separated by 1 to $2 \mathrm{~mm}$ of undisturbed sediment. The central ridges are longer and slightly more deeply impressed. All ridges taper consistently in one direction (fig. 8a, to the left) and thicken in the other. Specimen UBGM 20137 (fig. 8b) comprises two sets of slightly smaller, narrower, less deeply impressed ridges preserved in convex hyporelief. Each set consists of four, possibly five, ridges of unequal length

Fig. 7. a, Two examples of Cylindrichnus isp. preserved in concave epirelief on upper sandstone surface; MGUH 19.665 and MGUH 19.666 from GGU collection 239665-14. b, Dimorphichnus isp. preserved in convex hyporelief on a sandstone sole; MGUH 19.667 from GGU collection 314801-4. c, Gyrolithes saxonicus preserved in endorelief; MGUH 19.668 from GGU collection 239665-6. d, Helminthopsis tenuis preserved in convex hyporelief on sandstone sole; MGUH 19.669 from GGU collection 314834-5 and 314834-6, two parts of the same slab which are rejoined in the illustration. 


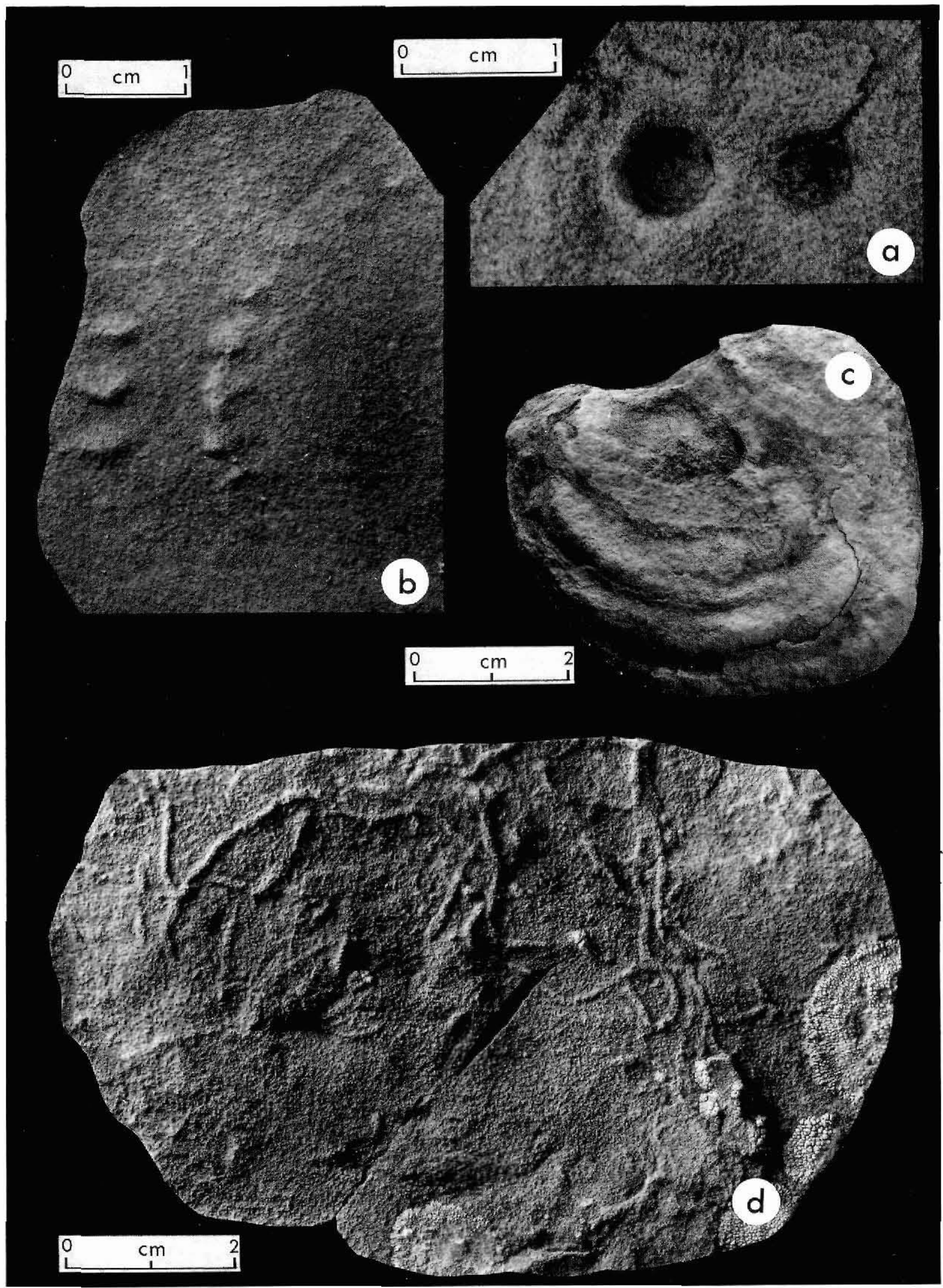


and impression similar to UBGM 20136 as described above.

Remarks. Cowie \& Spencer (1970, p. 97, pl. 2a, 2b) figured the material described here but only referred it to as 'arthropod scratch marks'. However, we concur with Fritz \& Crimes (1985) and Crimes (1987) that the material can be assigned to Monomorphichnus. We regard it as conspecific with $M$. lineatus, originally defined by Crimes et al. (1977), which is characterised by sets of isolated, straight to sigmoidal ridges (or corresponding grooves). M. bilineatus Crimes, 1970 possesses ridges associated in pairs. M. pectenensis Legg, 1985 also has paired straight ridges but possesses intervening fine, comb-like striations.

\section{Ichnogenus Neonereites Seilacher, 1960}

Neonereites biserialis Seilacher, 1960

Fig. 8c

Material. One specimen from GGU collection 239665-18.

Description. The small and incomplete specimen is poorly preserved in convex hyporelief on a sandstone sole and consists of two rows of subcircular sediment pods. One row (upper row in fig. 8c) comprises four pods arranged slightly arcuately, individual pods being separated by a very small gap $(0.3$ to $0.5 \mathrm{~mm})$. The second row comprises four more irregularly sized and disposed pods which may or may not be juxtaposed. Individual pods vary in size from 0.2 by $0.3 \mathrm{~mm}$ to 0.4 by $0.5 \mathrm{~mm}$; total length of the trace is $1.7 \mathrm{~cm}$.

Remarks. The ichnogenus Neonereites has been the topic of much nomenclatural controversy since Seilacher \& Meischner (1965) first considered it to be a behavioural variant, but not synonymous with the related ichnogenera Nereites Macleay, 1839 and Scalarituba Weller, 1899. Chamberlain (1971) actually synonymised it with Scalarituba, the definition of which he expanded to include a 'Nereites view' in convex hyporelief and a 'Phyllodocites view' in concave epirelief. However, as more fully discussed by Fillion \& Pickerill (1990), most subsequent authors, as we do herein, have preferred to retain Neonereites as a distinctive ichnogenus (see also Crimes, 1987).
Three ichnospecies are currently recognised, $N$. uniserialis Seilacher, 1960, N. biserialis Seilacher, 1960 and N. multiserialis Pickerill \& Harland, 1988, being composed, respectively, of uniserial, biserial and multiserial rows of sediment pustules or pods. The single specimen described here, although poorly preserved, can be assigned to $N$. biserialis.

\section{Ichnogenus Palaeophycus Hall, 1847}

Palaeophycus striatus Hall, 1852

Figs 9a,b

Material. Four specimens from GGU collections 314801-9, 314834-10, 314834-11, 239917-5.

Description. Simple, unbranched, horizontal to subhorizontal burrows preserved on upper sandstone surfaces, with each burrow combining preservation in concave and convex epirelief through its exposed length. Each possesses poorly preserved fine, parallel, longitudinal striations which, however, are not preserved through the entire burrow length, probably as a result of relatively coarse grain size. Burrows are straight to curved, approximately $4 \mathrm{~mm}$ in diameter, up to $9 \mathrm{~cm}$ in length, possess a fill of similar grain size to the host rock and an extremely thin lining of finer-grained material.

Remarks. Differentiation of the morphologically similar ichnogenera Palaeophycus Hall, 1852 and Planolites Nicholson, 1873 was addressed by Pemberton \& Frey (1982) and more recently Fillion (1989). Fillion \& Pickerill (1990) emended the diagnoses of these two ichnogenera, and also discussed their relationship to the morphologically similar burrow Macaronichnus Clifton \& Thompson, 1978. Material from the Bastion Formation possesses a burrow fill of similar grain size to the host rock and burrow walls that are lined and possess parallel and longitudinal striations, thus permitting assignment to $P$. striatus.

Collections containing $P$. striatus also contain additional examples of epichnial grooves (as described later) and $P$. tubularis (as described below) and therefore the distinction between these three ichnotaxa, at least in these collections, would appear to be dependent on the variable and differential preservation exhibited between individual specimens.

Fig. 8. a, b, Monomorphichnus lineatus preserved in convex hyporelief on sandstone soles; a is UBGM 20136 and b is UBGM 20137. c, Neonereites biserialis with an approximately horizontal axis preserved in convex hyporelief on sandstone sole; MGUH 19.670 from GGU collection $239665-18$. 


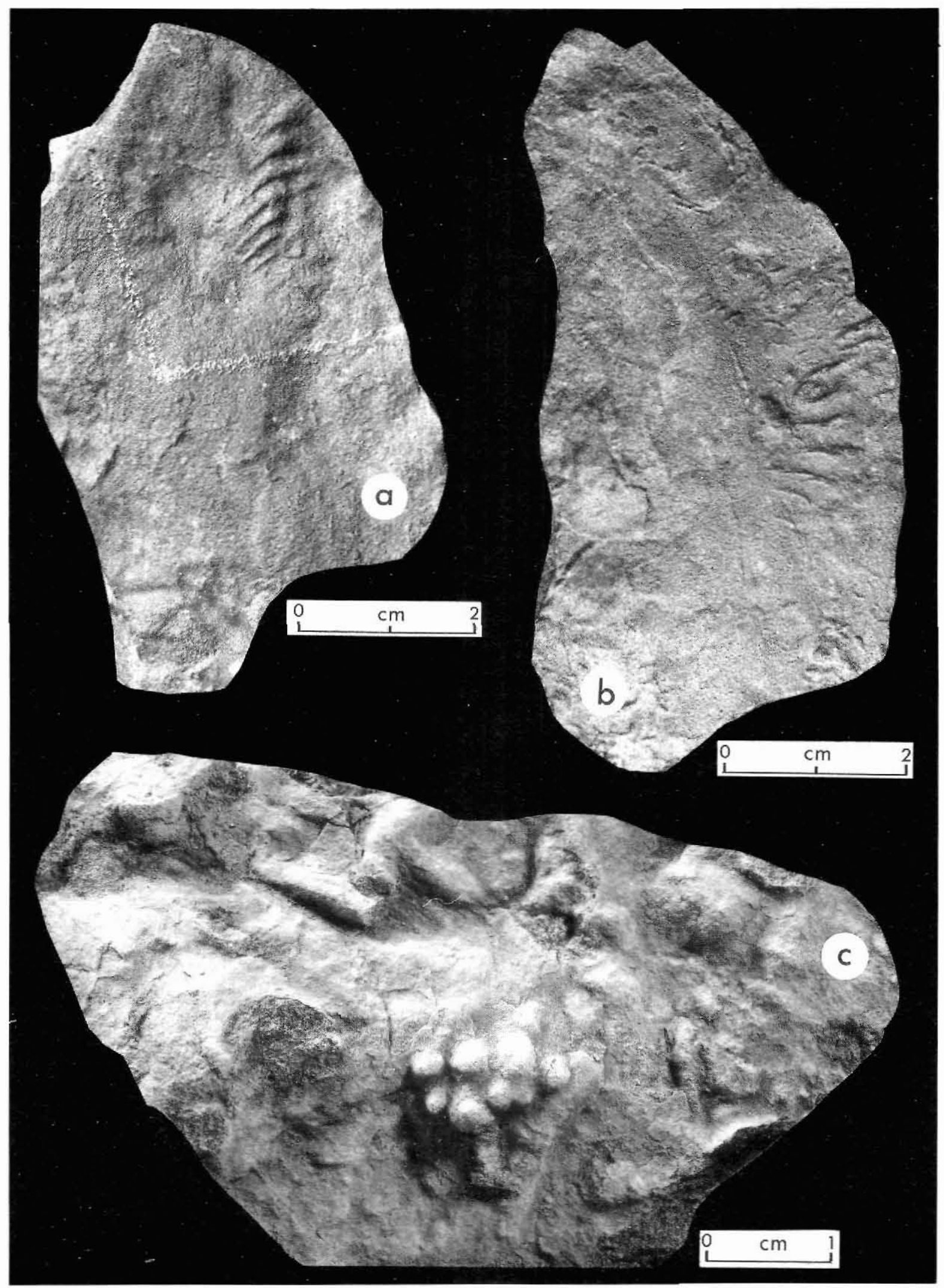


Palaeophycus tubularis Hall, 1847

Figs $9 \mathrm{c}, 10 \mathrm{a}, \mathrm{b}$

Material. More than 60 specimens from GGU collections 314834-12, 314834-15, 314834-17, 314834-18, $314801-7,314801-8,314801-9,314801-10,239665-4$, 239665-10, 239665-19, 239607-2, 239916-2, 239916-3, 239918-3; UBGM 20135.

Description. Most specimens comprise simple, unbranched, horizontal to sub-horizontal burrows, preserved essentially in convex hyporelief and convex epirelief. Burrows are straight to curved to slightly tortuous, smooth and unornamented, thinly lined and possess a fill of similar grain size to the enclosing sediment. Dimensions are variable, up to a maximum $8 \mathrm{~mm}$ in diameter and $15 \mathrm{~cm}$ in length. Rare examples (e.g. fig. 10a) possess a 'beaded' lower surface along portions of their length; other examples exhibit evidence of burrow collapse, particularly those specimens preserved essentially in convex epirelief, along small segments of their course.

Remarks. Following Pemberton \& Frey (1982) and Fillion (1989), these morphologically simple smooth burrows can best be assigned to $P$. tubularis. Notably, the rare 'beaded' examples strongly resemble $P$. tortuosus Hall, 1852, questionably synonymised with $P$. tubularis by Pemberton \& Frey (1982). Although we were unable to section or observe burrow linings in all specimens, we suspect, on the basis of their smooth external surfaces and fill of similar grain size to the enclosing sediment, that these are conspecific and also include them within $P$. tubularis. The thin wall-lining of $P$. tubularis is easily removed by weathering, commonly resulting in apparently unlined burrows which, nevertheless, belong to this ichnospecies (Howard \& Frey, 1984).

The above listed material represents only those collections in which the ichnospecies is clearly defined or occurs commonly. Other collections typically contain the ichnotaxon, as it is the most abundant trace fossil within the Bastion Formation; they are omitted from the description because of poor preservation.
Ichnogenus Phycodes Richter, 1850

Phycodes palmatus (Hall, 1852)

Fig. 9d

Material. Two specimens one each from GGU collection 314801-7, and GGU collection 239665-10.

Description. The figured specimen is preserved essentially in convex hyporelief on a sandstone sole (fig. 9d); it consists of a 9 to $13 \mathrm{~mm}$ wide, smooth, horizontal and incomplete master burrow from which ramify six, possibly seven, other horizontal, slightly curved, burrows that radiate outwards from one side of the master burrow so that the entire system assumes a palmate or digitate form. Diameter of the unbranched secondary burrows varies from 8 to $11 \mathrm{~mm}$ and length is at least 13 $\mathrm{cm}$ in a single example. Their distal extremities are typically preserved in concave hyporelief. The secondary burrows originate at slightly different levels from the master burrow; thus the presence of a spreite can be inferred, even though the proximal portion was not vertically sectioned. Burrow fill is similar in grain size to the enclosing sediment; burrow surfaces are smooth and unornamented.

The second specimen is less well preserved and smaller; six $4 \mathrm{~mm}$ diameter, smooth, unbranched burrows ramify from a short initial master shaft in a fashion to that described above. The presence of a spreite can again be inferred as the secondary burrows are at slightly different levels within the enclosing sandstone.

Remarks. Since Buthotrephis palmata Hall, 1852 was first regarded as an ichnospecies of Phycodes by Seilacher (1955) the ichnotaxon has been referred to as $P$. palmatum in ichnological literature. However, as pointed out by Fillion \& Pickerill (1990), Phycodes is a substantivated adjective and is masculine and the ichnotaxon should therefore be referred to as $P$. palmatus. $P$. palmatus is distinguished from other ichnospecies of Phycodes by its simple horizontal palmate form (for review see Fillion \& Pickerill, 1990). The most similar ichnospecies, P. curvipalmatus Pollard, 1981, has shorter and more curved branches compared to $P$. palmatus.

The interpretation and detailed taxonomy of Phycodes have been extensively treated by Mägdefrau (1934), Seilacher (1955), Osgood (1970) and Fillion \& Pickerill (1990).

Fig. 9. a, b, Palaeophycus striatus preserved on upper sandstone surfaces in positive epirelief; a is MGUH 19.671 from GGU collection 314834-11, b is MGUH 19.672 from GGU collection 314801-9. c, Palaeophycus tubularis preserved in positive epirelief on upper ripple-marked sandstone surface, MGUH 19.673 from GGU collection 314834-18. The same specimen is also shown in fig. 10b. d, Phycodes palmatus preserved in positive hyporelief on a sandstone sole, MGUH 19.674 from GGU collection 239665-10. 


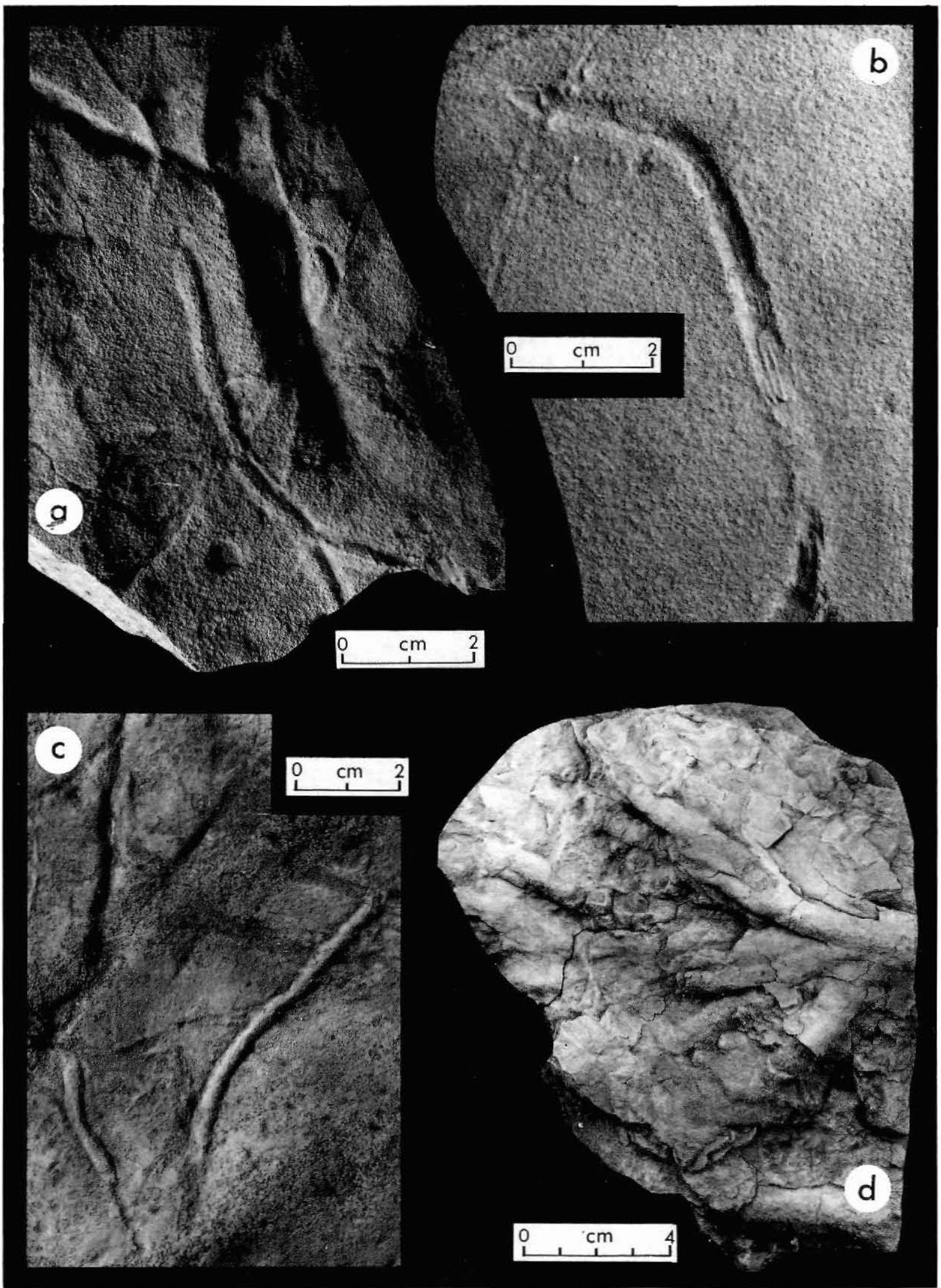


Ichnogenus Plagiogmus Roedel, 1929

Plagiogmus isp.

Figs 10b-e

Material. Seven, possibly eight, specimens from GGU collections $\quad 314834-17, \quad 314834-18, \quad 314834-19$, 314834-20, 239665-1, 239665-12, ?239916-2.

Description. Specimens are preserved on upper sandstone surfaces and consist of straight, curved to sinuous, isolated or rarely intersecting horizontal epirelief structures comprising a central flattened portion, preserved in concave epirelief, that possesses straight to slightly arcuate transverse ribs, preserved in convex epirelief. The central flattened portion is flanked by variably preserved external ridges, preserved in convex epirelief, that are typically straight but rarely exhibit slight convexity between individual transverse ribbed sections. The transverse ribs are 1 to $2 \mathrm{~mm}$ thick and extend to, or closely approach, the marginal ridges but never extend beyond them; they are variably developed but commonly are irregularly spaced within individual specimens. Though of variable dimensions, each specimen is typically 1.7 to $2.5 \mathrm{~cm}$ wide; the maximum observed length is $40 \mathrm{~cm}$.

The specimen illustrated as fig. 10e is also preserved on an upper sandstone surface but at two stratification levels, and preserves the lower (similar to the above description) and the upper surfaces of the trace. The lower surface is a short, $2.5 \mathrm{~cm}$ long, and narrow, $0.8 \mathrm{~cm}$ wide, flattened section with pronounced marginal ridges preserved in convex epirelief and each approximately 1 $\mathrm{mm}$ wide. The upper surface consists of a variably preserved, $13.5 \mathrm{~cm}$ long, bilobed section of variable width $(1.7$ to $2.5 \mathrm{~cm})$ preserved in convex epirelief. The lobes exhibit only moderate and slightly variable relief and are separated by a 2 to $3 \mathrm{~mm}$ wide axial furrow of variable but typically small depth. A portion of one of the lobes exhibits imbricated sediment pads.

Remarks. Specimens illustrating the lower portions of the traces closely resemble $P$. arcuatus Roedel, 1929, subsequently designated by Häntzschel (1962, p. W210) as the type ichnospecies, from the Lower Cambrian of Sweden, but are not as well preserved. Jaeger \& Mar- tinsson (1980) restudied Roedel's types and, with the addition of topotype material, they demonstrated that $P$. simplex Roedel, 1929 was a synonym of $P$. arcuatus, though earlier Häntzschel (1964) and Glaessner (1969) reported them as distinct ichnospecies. Jaeger \& Martinsson (1980) also demonstrated that $P$. arcuatus possessed a smooth unilobate upper surface which obviously differs from the bilobate and partially imbricated upper surface of the material described here. For this reason we only identify the material at the ichnogeneric level, but note that the ichnogenus remains monospecific, to our knowledge, providing Jaeger \& Martinsson's (1980) conclusions are correct with respect to $P$. simplex. Indeed, most authors (e.g. Glaessner, 1969; Banks, 1970; Cloud \& Bever, 1973; Peterson \& Clark, 1974; Crimes et al., 1977; Fritz \& Crimes, 1985) have preferred to identify the trace only at the ichnogeneric level, despite the material, in some cases, being extremely well preserved.

In view of the morphological and preservational variability exhibited by the ichnogenus (see above cited references) it is an obvious candidate for taxonomic re-assessment at the ichnospecific level. We disagree with Fritz \& Crimes (1985, p. 15) that the type material needs redescription as we feel that Jaeger \& Martinsson's (1980) analysis of the types is perfectly adequate for comparative purposes.

The specimen illustrated in fig. 10e is of particular interest as it preserves both lower and upper surfaces of Plagiogmus; upper views are extremely rare in comparison to well-documented epirelief and hyporelief lower counterparts. As noted above, Jaeger \& Martinsson (1980) figured and described a unilobate upper surface of a single specimen of $P$. arcuatus. Peterson \& Clark (1974, p. 766, pl. 1, fig. 2) also figured upper surfaces preserved in both convex and concave epirelief and although apparently unilobate their exact nature cannot be determined from the plate. Singh \& Rai (1983) described Plagiogmus possessing indistinct, smooth and rather flattened upper surfaces from the Lower Cambrian Tal Formation of the Lesser Himalaya. Kruse \& West (1980) figured a specimen of Plagiogmus preserving both lower and upper surfaces. It possessed a betterpreserved and more obviously transversely ribbed lower surface than the specimen described here, and a bilobed

Fig. 10. a, Palaeophycus tubularis preserved in convex hyporelief on a sandstone sole, MGUH 19.675 from GGU collection 314801-8. b, upper surface of ripple-marked sandstone slab representing GGU collection 314834-18 and illustrating Palaeophycus tubularis (arrowed), as illustrated in more detail in fig. $9 \mathrm{c}$, and Plagiogmus isp., as illustrated in more detail in fig. 10c. c, detailed view of central portion of Plagiogmus isp. as shown in fig. 10b, MGUH 19.676 from GGU collection 314834-18. d, Plagiogmus isp. preserved in epirelief on upper sandstone surface, MGUH 19.677 from GGU collection 314834-17. e, Plagiogmus isp. illustrating the bilobed upper surface which possesses imbricated sediment pads and a short section of the corresponding lower surface (arrowed); MGUH 19.678 from GGU collection 239665-12. 


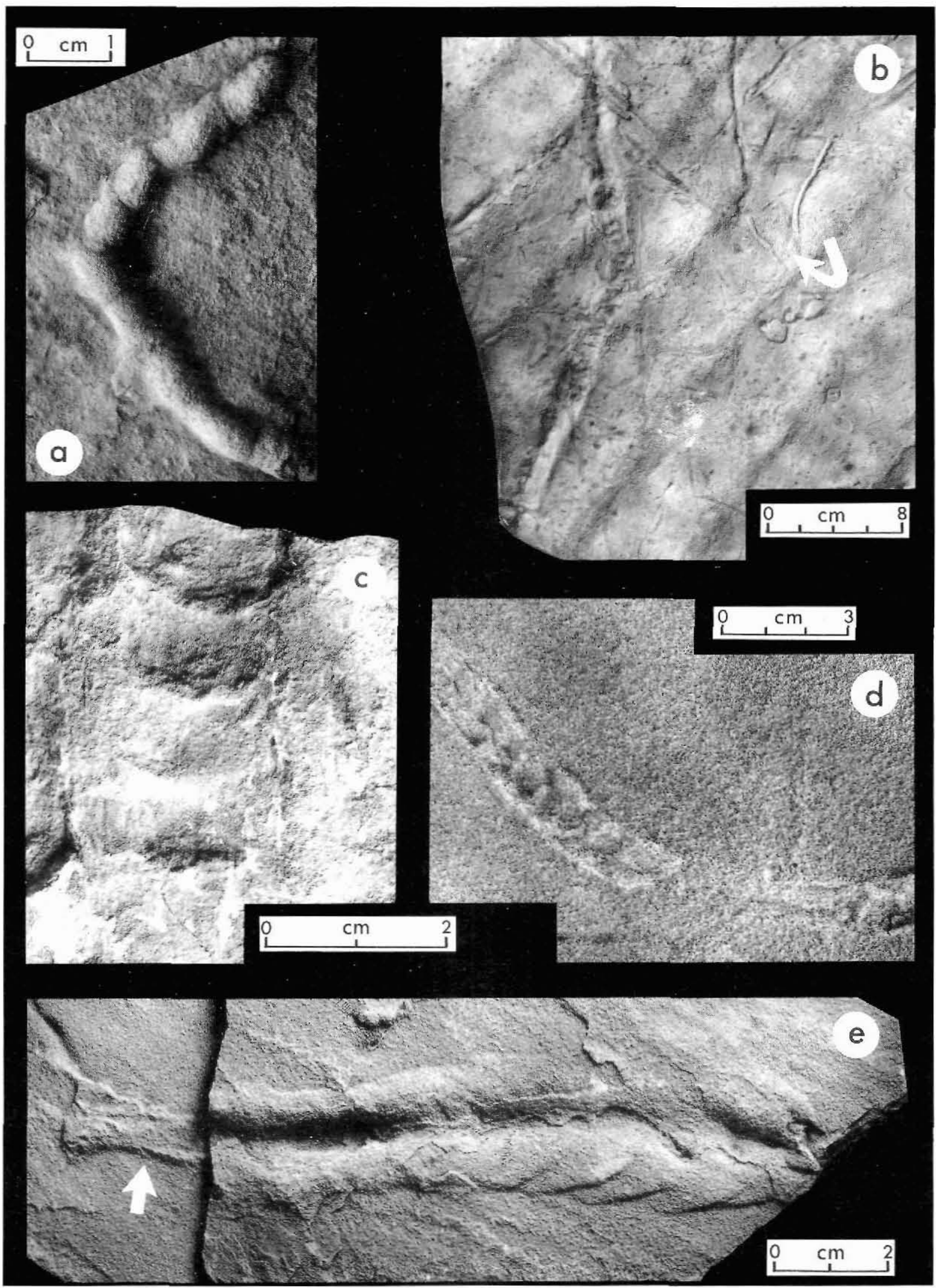


upper surface with a well-developed median longitudinal groove. These authors noted that the 'molluscan trails' previously figured by Glaessner $(1969$, p. 388 , figs 9B-D) strongly resembled the upper view of their Plagiogmus, and, indeed, referred these to the ichnogenus. The figured specimen of Kruse \& West $(1980$, p. 168, fig. 4) did not exhibit the backfilled imbricated sediment pads, described herein and predicted by Glaessner (1969) in his 3-dimensional reconstruction of the trace which he correctly interpreted as an endichnial burrow (see also Jaeger \& Martinsson, 1980). To our knowledge this is the first record of backfilled imbricated sediment pads within the ichnogenus.

These backfilled sediment pads are reminiscent of those observed in a portion of the ichnogenus Psammichnites Torell, 1870 described by Bryant \& Pickerill (1990) from the Lower Cambrian Buen Formation of central North Greenland. Indeed, as first noted by Glaessner (1969, p. 387), both Plagiogmus and Psammichnites are currently considered to represent endichnial burrows produced by primitive molluscs and the complex and variable behaviour of the producers could potentially result in intergradational forms making assignment to one or the other extremely difficult, particularly if only poorly preserved or incomplete material was available.

Glaessner (1969) and more recently Crimes (1987, 1989) suggested that Plagiogmus was stratigraphically restricted to pre-trilobite late Tommotian to early Atdabanian strata. This is clearly an oversimplification, however, as undoubted examples of the ichnogenus have been recorded from the Middle Cambrian of Utah (Peterson \& Clark, 1974) and Montana and possibly Wyoming (Cloud \& Bever 1973). Possible preservational variants have also been reported by Pickerill $e t$ al. (1984) from the Middle Ordovician of eastern Canada and Whitaker (1979) from the Upper Silurian to Lower Devonian of southern Norway (as Steinsfjordichnus brutoni Whitaker, 1979). Thus, while most commonly reported from strata of Early Cambrian age (see Crimes, 1987), its stratigraphic range is considerably more extensive.
Ichnogenus Psammichnites Torell, 1870

\section{Psammichnites gigas (Torell, 1868) \\ Figs 11a-c}

Material. Five, possibly six, specimens from GGU collections 239665-11, 239665-13, 239607-1, 239607-3 and a possible example in UBGM 20135.

Description. Specimens exhibit variable morphology depending on style of preservation and level of view. The specimen illustrated at the extreme left in fig. 11a is preserved on a top surface and consists of a slightly raised, smooth, bilobed, straight to gently curved band, up to $17 \mathrm{~cm}$ in length and $2.4 \mathrm{~cm}$ in width. An axial furrow separates the two lobes but this feature is variably developed along the length of the specimen, so that in places the band appears almost unilobed. Individual lobes are flattened or very gently convex; they possess steep, almost vertical, outer margins so that where the axial furrow is developed the specimens displays an m-shaped cross-sectional profile. The specimen to the right in fig. 11a is morphologically similar, being preserved on the same bedding surface, but is less well preserved.

An additional specimen (fig. 11b) is preserved on a lower surface and comprises a straight, unilobed band (16 cm long, $3.3 \mathrm{~cm}$ wide) preserved in convex hyporelief. The trace is gently convex and possesses sharp and clearly defined straight external margins. Delicately preserved, evenly spaced, transverse arcuate striations are present on the external surface of the specimen but these proved almost impossible to reproduce photographically.

We suspect that a third preservational variant (fig. 11c) is also preserved on a lower surface. The specimen consists of a small and incomplete segment of a curved band, $7 \mathrm{~cm}$ in length along the median axis, and $1.2 \mathrm{~cm}$ in width. As with the specimen described above (fig. $11 b)$, the trace is unilobed and gently convex with clearly defined outer margins. However, a narrow (1.5 $\mathrm{mm})$ and slightly raised $(1 \mathrm{~mm})$ median ridge extends down the length of specimen. Crudely developed, transverse ornamentation is present on some segments of the trace.

Remarks. The taxonomy of Psammichnites and morphologically similar ichnogenera, such as Olivellites Fen-

Fig. 11. a, Psammichnites gigas preserved in epirelief on an upper sandstone surface, MGUH 19.679 (extreme left) and MGUH 19.680 (to the right) from GGU collection 239607-1. b, Psammichnites gigas preserved on a lower sandstone surface in positive hyporelief, MGUH 19.681 from GGU collection 239665-11. c, Psammichnites gigas preserved on an unknown upper or lower sandstone surface but illustrating a well-developed median ridge and crude transverse ornamentation (arrowed); MGUH 19.682 from GGU collection 239665-13. 


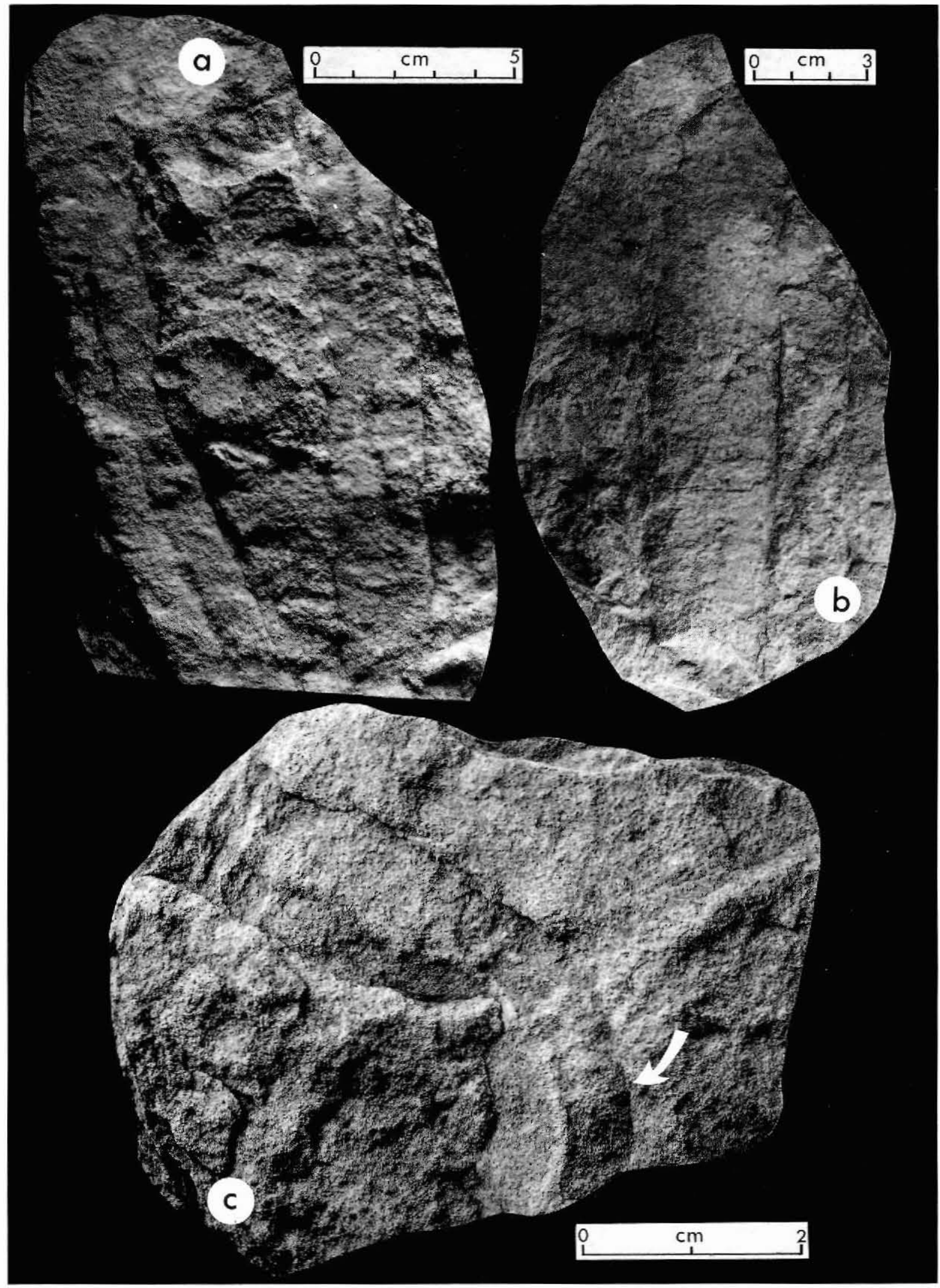


ton \& Fenton, 1937a, Aulichnites Fenton \& Fenton, 1937b and Laminites Ghent \& Henderson, 1966, is still in a state of confusion. In part, this is because it is still not clear as to whether or not Torell's (1868, pl. 1, fig. 2) original illustration represents its upper or lower surface (Fillion \& Pickerill, 1990). Seilacher (1955) grouped Psammichnites with Scolicia de Quatrefages, 1849, as did Häntzschel (1962) who did not regard it, however, as a synonym. Fisher \& Paulus (1969) selected the largest of Torell's four species, Arenicolites (Psammichnites) gigas, as the type ichnospecies and Häntzschel (1975) subsequently regarded it as a distinctive ichnotaxon. Chamberlain (1971) considered Olivellites to be a junior synonym of Psammichnites and D'Alessandro \& Bromley (1987) placed Olivellites and Aulichnites as junior synonyms of Psammichnites, regarding Laminites as an additional possible synonym. However, Hofmann \& Patel (1989) and Fillion \& Pickerill (1990) argued that Aulichnites should be retained pending redescription and vertical sectioning of at least topotype material of Psammichnites. Additionally, if Torell's material proves to be preserved in convex hyporelief, as we suspect from comparison of material described here, then Psammichnites clearly differs from Olivellites. The latter is preserved in convex or concave epirelief (see Yochelson \& Schindel, 1978; Eager et al., 1985) and therefore possesses a totally different 3-dimensional configuration. More recent authors (e.g. Plaziat \& Mahmoodi, 1988) have also retained Olivellites as a distinct ichnotaxon.

Complete knowledge of Laminites, its morphological range and preservational variants, is also lacking, though Plaziat \& Mahmoodi's (1988, p. 222, fig. 13) reconstruction does favour incorporation within Psammichnites as tentatively proposed by D'Alessandro \& Bromley (1987). Although it is clear that there is still much confusion regarding these varied ichnogenera, we follow current usage and utilise Psammichnites for relatively large burrows or trails with bilobed upper surfaces and steep outer margins (cf. Hofmann \& Patel, 1989; Fillion \& Pickerill, 1990).

Classification at the ichnospecific level is equally as unsatisfactory and re-study of Torell's (1870) material and other ichnospecies of Psammichnites is considered necessary. Indeed, most recent authors have only identified it at the ichnogeneric level (e.g. Fisher \& Paulus, 1969; Brasier et al., 1978; McCarthy, 1979; Brasier \&
Hewitt, 1979; Chaplin, 1980) and several such identifications, even at the ichnogeneric level, are tenuous at best.

Hofmann \& Patel (1989) provided a comprehensive description and analysis of $P$. gigas from the Lower Cambrian of New Brunswick, eastern Canada. Material from the Bastion Formation falls well within the morphological range of the New Brunswick samples (R. K. P., personal observation) and, pending re-assessment of types, we regard the material as conspecific. Hofmann \& Patel's (1989, p. 145, fig. 5) schematic reconstruction of the ichnospecies clearly demonstrates that it represents an endichnial burrow (see also Fillion \& Pickerill, 1990); their material is preserved as dorsal and ventral views which correspond to the first two preservational variants described here. Interestingly, the third preservational variant is not present in their material but is almost identical to Torell's (1868, pl. 1, fig. 2) type as figured, for example, by Häntzschel (1975, p. W100, fig. 62.2c). Clearly, $P$. gigas is a most complex ichnotaxon which exhibits a wide range of internal and external morphologies, presenting different morphologic aspects depending on level of view.

Finally, Scolicia figured by Cowie \& Spencer (1970, p. 94, pl. 1a) is tentatively referred to $P$. gigas, a conclusion also made by Hofmann \& Patel (1989). This specimen exhibits the ventral surface view of the burrow and, although somewhat flattened, possesses densely spaced ( 6 to 8 per $\mathrm{cm}$ ) transverse to slightly arcuate striations, with clearly defined, 1 to $2 \mathrm{~mm}$ wide, marginal grooves. This latter feature has not been observed in other specimens from the Bastion Formation and so this comparison is only tentative. Hofmann \& Patel (1989) also questionably included Scolicia figured by Crimes et al. (1977, p. 123, pl. 7d) from the Lower Cambrian of Spain within Psammichnites. However, this is preserved on an upper sandstone surface and does not conform to the reconstruction of Psammichnites by Hofmann \& Patel (1989); it is best still regarded as Scolicia.

\section{Ichnogenus Rosselia Dahmer, 1937}

\section{Rosselia socialis Dahmer, 1937}

Figs 12a,b

Material. Three specimens from GGU collections 239665-21, 239918-2, 239918-5.

Fig. 12. a, b, oblique and lateral views of Rosselia socialis preserved in full relief in a laminated sandstone, MGUH 19.683 from GGU collection 239665-21. c, d, lower and oblique views of Rusophycus dispar, MGUH 19.684 from GGU collection 239917-3, in association with Cruziana cf. C. fasciculata (arrowed), as shown in more detail in fig. 4d. In c, p represents location of second-order scratches and o represents third-order scratches (for details see text). e, Rusophycus isp. preserved in convex hyporelief on a sandstone sole, MGUH 19.685 from GGU collection 239918-6. 


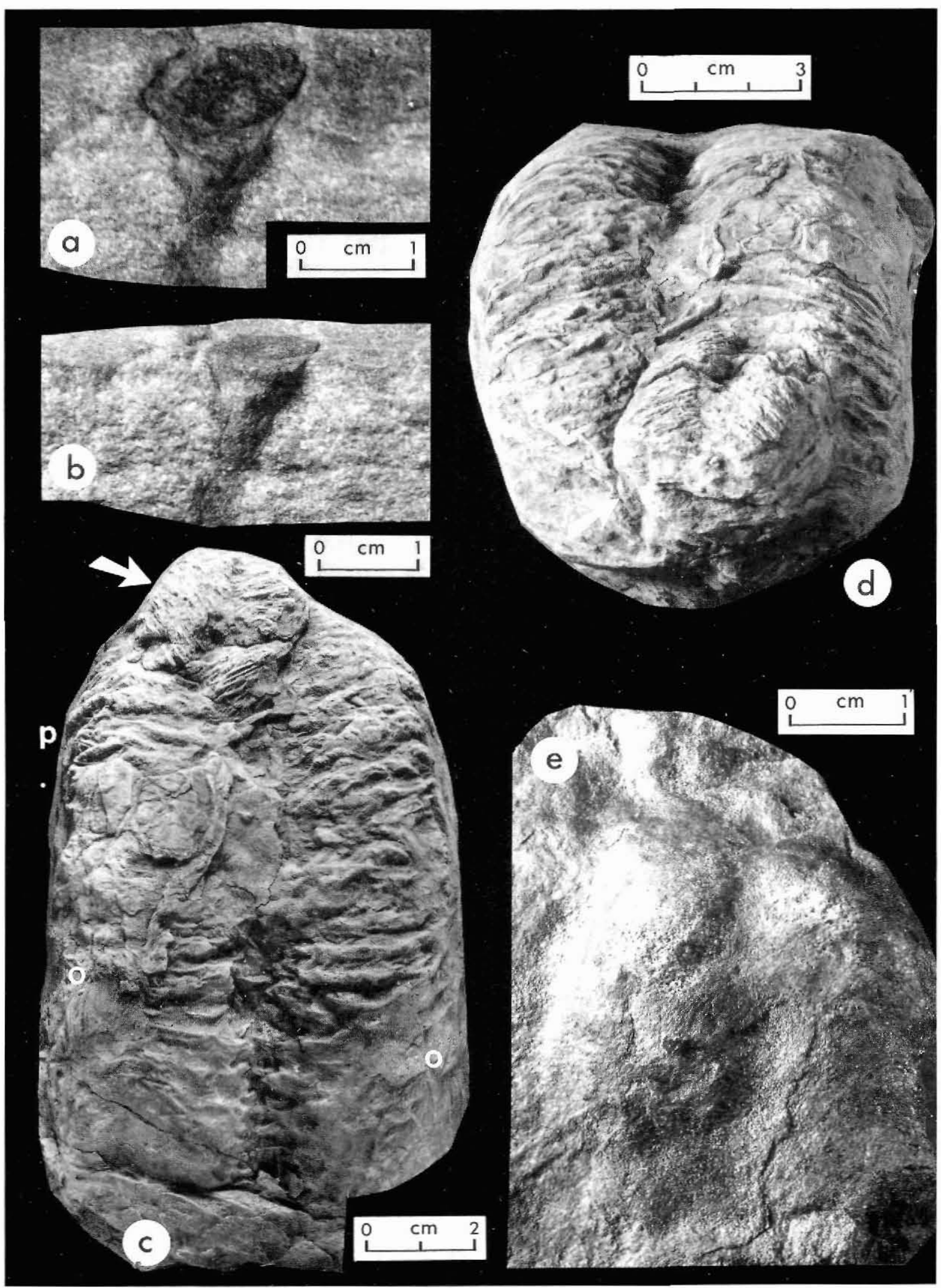


Description. The figured specimen is a funnel-shaped, steeply inclined, sharp-walled, incomplete burrow preserved in full relief within a parallel-laminated sandstone (fig. 12a,b). The upper flared portion is $1.15 \mathrm{~cm}$ in diameter and this tapers downwards through the $2 \mathrm{~cm}$ thick slab to become $0.4 \mathrm{~mm}$ in diameter at its exposed base. The burrow possesses a concentrically laminated fill throughout; burrow fill is darker in colour and slightly finer-grained than the host material. Laminae adjacent to the burrow are not deflected.

The additional two specimens are less well preserved and generally incomplete, but clearly possess similar characteristics. The specimen from GGU collection 239918-5 has an upper funnel width of $0.9 \mathrm{~cm}$ and tapers downwards for at least $1.2 \mathrm{~cm}$. The specimen from GGU collection $239118-2$ has a $1.4 \mathrm{~cm}$ wide top which tapers down to a $0.6 \mathrm{~mm}$ wide tube. Both are concentrically lined.

Remarks. Although Seilacher (in Häntzschel, 1975, p. W101) considered the ichnogenus Rosselia to be a junior synonym of Asterosoma von Otto, 1854, most subsequent authors (e.g. Howard \& Frey, 1984; Frey \& Bromley, 1985; Frey \& Howard, 1985; Miller \& Knox, 1985; D'Alessandro \& Bromley, 1986) retain it as a distinctive ichnogenus, as we do herein. Fillion \& Pickerill (1984) and Frey \& Howard (1985) have outlined the differences between these two ichnogenera together with the morphologically similar ichnogenus Cylindrichnus Toots in Howard, 1966. Indeed, basal stems of Rosselia are identical in construction to Cylindrichnus. Although the overlap in morphology presents a potential problem in their differentiation, the presence of a laminated fill helps distinguish both Rosselia and $C y$ lindrichnus from the morphologically similar ichnogenus Monocraterion Torell, 1870, the base of which is a simple shaft (Frey \& Howard, 1985). Rosselia is easily identifiable if the funnel-shaped upper portion of the burrow, with its distinctive concentrically lined fill, is preserved. Nevertheless, a range of preservational variants can exist where assignation to one or the other of these ichnogenera is difficult (see Howard \& Frey, 1984; Frey \& Bromley, 1985).

The specimens are rather small compared to most previously described examples of $R$. socialis, though Frey \& Howard (1985) and Fillion \& Pickerill (1990) do describe material of comparable size and Chamberlain (1971) has described even smaller examples. However, they clearly fall within the diagnosis of $R$. socialis, as defined by Dahmer (1937), and are regarded as conspecific. They differ from the two other currently commonly recognised ichnospecies, $R$. rotatus McCarthy, 1979 and $R$. chonoides Howard \& Frey, 1984, in having concentric laminae and lacking helicoidal swirls or crescentic backfill structures formed by rotary movements of the tube within the funnel.

Ichnogenus Rusophycus Hall, 1852

Rusophycus dispar Linnarsson, 1869

Figs $12 \mathrm{c}, \mathrm{d}$

Material. One specimen from GGU collection 239917-3.

Description. The specimen consists of an almost complete, moderately well preserved, deeply impressed bilobed trace preserved in convex hyporelief on a sandstone sole. Estimated length is $12.5 \mathrm{~cm}$ and maximum width is $8.2 \mathrm{~cm}$ to give a shape factor (length divided by width, see Crimes, 1970) of approximately 1.5. Maximum depth, developed towards the anterior portion of the specimen, is $3.2 \mathrm{~cm}$. The trace is essentially straightsided but broadens slightly anteriorly. Each lobe is separated by a moderately deep (fig. 12d) but variably preserved axial furrow which ranges in width from 2 to 5 $\mathrm{mm}$ and generally widens anteriorly. The anterior extremity is cut by a small segment of Cruziana cf. $C$. fasciculata (figs 12c,d).

Each lobe possesses three types of variably developed and preserved scratches. The most obvious of these are sharp, wide (up to $2 \mathrm{~mm}$ ), deeply impressed, essentially transverse scratches, that are typically unifid, more rarely bifid or trifid, particularly towards the outer margins of the lobes. Herein, these are termed first-order scratches. These scratches extend from the axial furrow across the entire lobes; they vary in depth and width and tend to become slightly proverse towards the anterior end of the specimen. Second-order scratches (fig. 12c-p) are thinner, less deeply impressed and isolated, or occur in bundles of up to at least three. These scratches are located between the first-order scratches and only towards the outer margins of the lobes at the anterior end of the specimen. Third-order scratches (fig. 12c-o), conversely, are only located at the posterior end of the specimen but again towards the external margins of the lobes. They consist of very finely impressed, densely spaced and essentially parallel scratches which run parallel to the external margins of the lobes; where they are present, first and second-order scratches are conspicuously absent.

Remarks. Following the interpretations of many previous authors (e.g. Seilacher, 1970; Bergström, 1973; Bergström \& Peel, 1988), the coarse and transverse scratches (first-order) were probably made by the telopodites or walking legs of the producing arthropod. The 
other scratches are more difficult to interpret, though we suspect that the intermediate, second-order scratches, located between the dominantly transverse scratches, are also a product of the telopodites. This is perhaps supported by the observation that, where present, they are located between first-order scratches that are essentially unifid; they are not present between first-order bifid or trifid scratches. The producing arthropod was obviously multi-digited, as revealed by the nature of the first-order scratches, which seems to support our explanation. The third-order scratches are herein interpreted as exite 'brushings' as not only do they resemble previously described exite-produced impressions on cruzianaeform and rusophyciform traces, but also they are located lateral to the telopodite-produced scratches. This latter observation is consistent with scratches interpreted as exite 'brushings' by previous authors (e.g. Seilacher, 1970; Bergström, 1973).

Our identification as $R$. dispar, based on only a single and incomplete specimen, clearly requires additional material for confirmation. Ideally, this ichnospecies, an integral component of the 'dispar group' of Seilacher (1970), should exhibit proverse and obverse scratches on, respectively, the anterior and posterior portions of the trace. Although the first-order scratches are slightly proverse towards the anterior end, no obverse scratches are observed. Nevertheless, the coarse and deep firstorder scratches, its relative depth and similarity with other examples of $R$. dispar (e.g. Linnarsson, 1869; Bergström, 1973; Alpert, 1976; Fillion \& Pickerill, 1990) suggest that the specimen is correctly identified. Additionally, as pointed out by Bergström \& Peel (1988), Seilacher's (1970) representations of the ichnospecies are highly schematic and do not represent the more typical preservation of the ichnospecies.

To date, $R$. dispar and its possible synonym Cruziana rusoformis Orlowski, Radwanski \& Roniewicz, 1970, are known only from Lower Cambrian to Tremadoc strata (Fillion \& Pickerill, 1990). The recording of Cruziana cf. dispar by Bandel (1973) from the Upper Devonian of Germany is best disregarded as this trace should clearly be assigned to a different ichnospecies.

\section{Rusophycus latus Webby, 1983}

Figs 13a,b

Material. Two specimens, one each from GGU Collection 239917-1 and GGU collection 239917-2.

Description. Both specimens are moderately well preserved in convex hyporelief on sandstone soles, each consisting of two moderately, but unequally impressed, well-defined lobes separated by a relatively shallow and imperfectly and variably preserved axial furrow. General outlines are essentially heart shaped. The first specimen (fig. 13a) is $12 \mathrm{~cm}$ wide, $11 \mathrm{~cm}$ long and is widest and deepest $(2.8 \mathrm{~cm})$ in its anterior portion. The second specimen (fig. 13b) is $7.7 \mathrm{~cm}$ wide, $7.5 \mathrm{~cm}$ long and 2.8 $\mathrm{cm}$ in maximum depth. Shape factors (Crimes, 1970) of both specimens are therefore approximately 0.9 .

Lobes possess sharp or rounded, unequally but clearly impressed, scratch marks that are 0.5 to $2 \mathrm{~mm}$ wide and 2.5 to $4 \mathrm{~mm}$ apart. The scratches are predominantly transverse but rarely may be deflected slightly forward immediately adjacent to the axial furrow. Though typically extending from the axial furrows across the convex lobes to their external margins, some scratches actually extend across the furrows. The scratches are typically unifid, rarely bifid and possibly trifid; bunching into discrete sets is not apparent.

Remarks. $R$. latus is characterised by a transversely elliptical, through subquadrate to heart-shaped outline, a shape factor of less than one, transverse scratches that are not grouped into sets and may cross the relatively shallow axial furrow, with lobes widest and deepest in the anterior half (Webby, 1983; Fillion \& Pickerill, 1990). The ichnospecies was first described from the Lower Ordovician of western New South Wales, Australia, by Webby (1983). Until now, only Fillion \& Pickerill (1990) have subsequently formally recorded it from elsewhere, though these authors did note that several of Bergström's (1976) specimens of Rusophycus cf. $R$. jenningsi (Fenton \& Fenton, 1937c) and Rusophycus isp. from the same Lower Ordovician sequence in eastern Newfoundland should more appropriately be regarded as $R$. latus. Webby (1983) did not provide a diagnosis, but the ichnospecies was validly erected; Fillion \& Pickerill (1990) have since provided a diagnosis and have discussed differences between morphologically similar ichnospecies. Although the records of $R$. latus herein apparently extend its range to the Early Cambrian, Alpert (1976) has figured similar, albeit smaller, traces from the Lower Cambrian of California (e.g. Alpert, 1976, p. 232, fig. 4).

\section{Rusophycus isp.}

Fig. 12e

Material. One specimen from GGU collection 239918-6.

Description. The specimen is poorly preserved in convex hyporelief on a sandstone sole and consists of two smooth lobes separated by a poorly developed smooth median furrow which widens quite markedly post- 


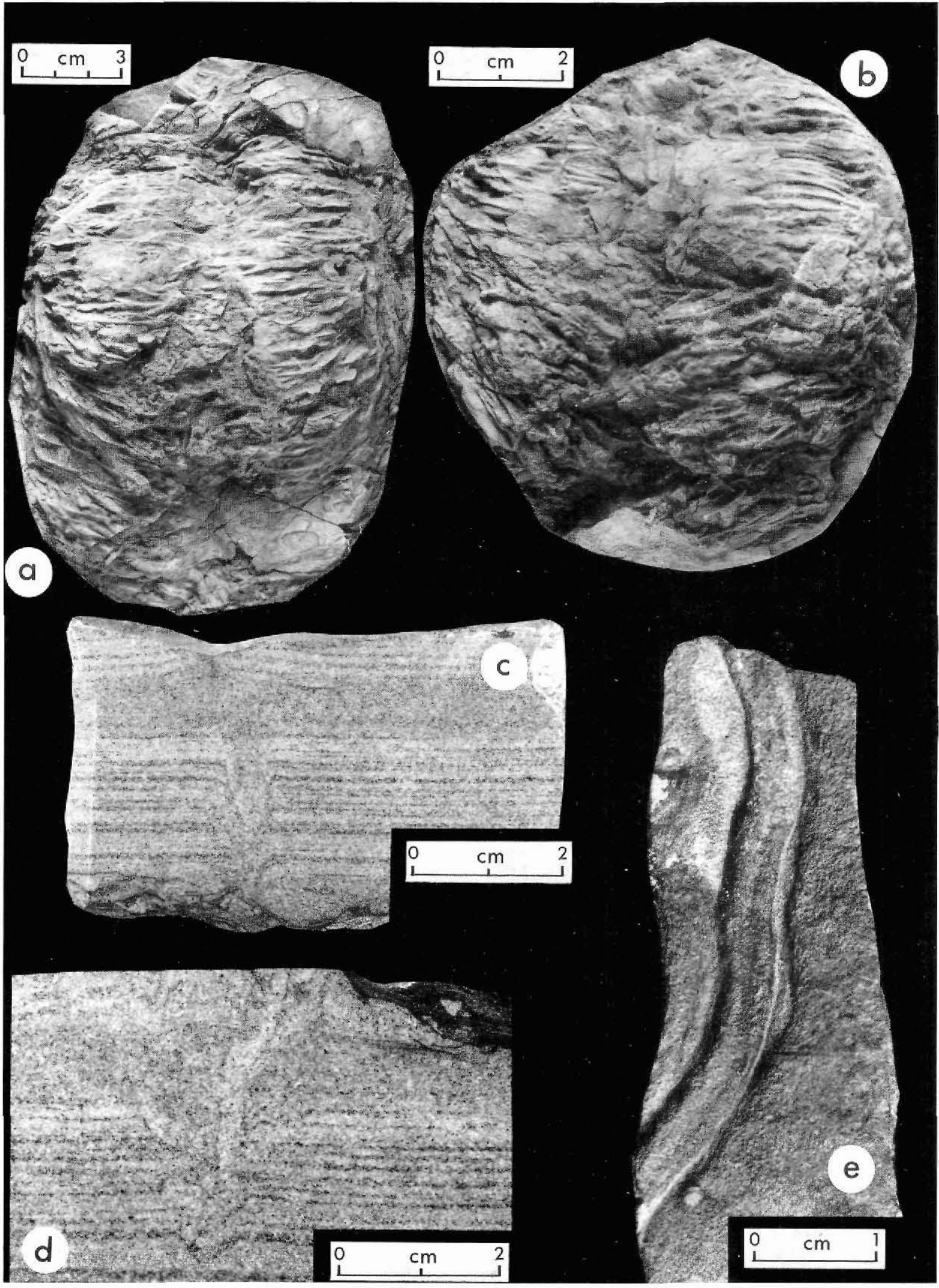


eriorly. The lobes are more deeply impressed, up to 0.4 $\mathrm{cm}$, anteriorly and then slope gently posteriorly until they merge with the sandstone sole. Maximum width is $4 \mathrm{~cm}$ and incomplete length $3.8 \mathrm{~cm}$ to give a shape factor (Crimes, 1970) of approximately one.

Remarks. The single specimen is so poorly preserved that ichnospecific assignment is impossible. We know of no comparable ichnotaxon, though it does vaguely resemble $R$. bonnarensis Crimes, Legg, Marcos \& Arboleya, 1977, as figured by Crimes et al. (1977, p. 107, pl. 3) from the Lower Cambrian of Spain. In overall shape it also resembles, particularly the anterior portion, $R u$ sophycus cf. $R$. dispar as figured by Alpert (1976, p. 232, pl. 2, fig. 1) but differs from this by the absence of scratches; nevertheless, this difference may be preservational.

\section{Ichnogenus Skolithos Haldeman, 1840}

Skolithos linearis Haldeman, 1840

Figs 13c,d

Material. At least fifteen specimens in GGU collections 239665-21, 239665-22, 239918-3, 314834-15 and UBGM 20135.

Description. The material is typically observed on upper surfaces as generally isolated, circular to oval structures preserved in both convex and concave epirelief and on lower surfaces in convex hyporelief. Vertical sectioning (figs 13c,d) reveals these to be planar expressions of vertical to sub-vertical, straight to slightly sinuous, unbranched, cylindrical to sub-cylindrical tubes. Diameter of the tubes varies from 3 to $8 \mathrm{~mm}$ and is relatively constant throughout the length. Maximum observed length is dependent on thickness of the collected slabs but is at least $4 \mathrm{~cm}$. Walls are typically distinct, more rarely indistinct, rarely thinly lined with mudstone and apparently smooth; burrow fill is of similar grain size to the enclosing host rock.

Remarks. As with several other commonly occurring ichnogenera, Skolithos has received considerable discussion and taxonomic evaluation. Although a thorough systematic review is undoubtedly necessary the nomenclatural scheme proposed by Alpert (1974) is regarded as still the most satisfactory for distinction at the ichnospecific level. Adopting this scheme, specimens from the Bastion Formation can be regarded as $S$. linearis. We note, however, that complete knowledge of the 3-dimensional form of Skolithos is necessary for ichnospecific assignment, and that those specimens not sectioned longitudinally could possibly belong to additional ichnospecies.

\section{Ichnogenus Taphrhelminthopsis Sacco, 1888}

Taphrhelminthopsis isp.

Fig. 13c

Material. One specimen from the collections made by Cowie \& Spencer (1970); UBGM 20138.

Description. The incomplete specimen is preserved in convex hyporelief on a sandstone sole and consists of a gently sinuous bilobed structure, $6.5 \mathrm{~cm}$ in total length and a constant width of $6 \mathrm{~mm}$. The lobes are smooth and somewhat flattened and are separated by a variably developed, approximately 1 to $2 \mathrm{~mm}$ wide, $1 \mathrm{~mm}$ deep, narrow axial furrow which is itself rather flattened. The external margins of the lobes are relatively steep and pass into 1 to $2 \mathrm{~mm}$ deep and wide marginal grooves which extend down the whole length of the specimen and are slightly more deeply impressed than the stratification plane preserving the specimen.

Remarks. This specimen was first figured by Cowie \& Spencer $(1970$, p. 97, pl. 2c) as an unidentified 'organic mark'. More recently Crimes et al. (1977, p. 126) and Crimes \& Jiang (1986, p. 647) tentatively referred the specimen to Taphrhelminthopsis circularis Crimes, Legg, Marcos \& Arboleya, 1977. Later, however, Crimes $(1987,1989)$ omitted the ichnogenus from his list of trace fossils occurring in the Bastion Formation of Greenland.

While we are in complete agreement with Crimes et al. (1977) and Crimes \& Jiang (1986) that this specimen can be assigned to Taphrhelminthopsis, we disagree with their tentative ichnospecific assignment. $T$. circularis is characterised, in part, by an irregularly circling habit (see Crimes et al., 1977; Crimes \& Anderson, 1985; Fritz \& Crimes, 1985; Crimes \& Jiang, 1986; Narbonne et al., 1987; Hofmann \& Patel, 1989) which clearly cannot be ascertained from the short and incomplete section of the specimen described here. Accordingly, the specimen is best identified only at the ichnogeneric

Fig. 13. a, b, Rusophycus latus preserved in convex hyporelief on sandstone soles. a is MGUH 19.686 from GGU collection 239917-1 and b is MGUH 19.687 from GGU collection 239917-2. c, d, Skolithos linearis in vertical section cutting laminated sandstone layer. $\mathrm{c}$ is MGUH 19.688 and $\mathrm{d}$ is MGUH 19.689, both from GGU collection 314834-15. e, Taphrhelminthopsis isp. preserved in positive hyporelief on a sandstone sole, UBGM 20138. 
level until additional material from the Bastion Formation becomes available for comparative purposes.

Ichnogenus Teichichnus Seilacher, 1955

Teichichnus rectus Seilacher, 1955

Figs $4 c$, 14a-c

Material. Seven, possibly eight, specimens from GGU collections 239922-1, 239922-2, 239918-1, ?239665-4.

Description. Specimens are preserved in full relief and consist of straight to slightly curved, typically smooth, unbranched burrows, parallel or slightly oblique to stratification and possessing a vertical retrusive spreite. Burrow length is variable, up to $13 \mathrm{~cm}$; depth cannot always be ascertained but is at least up to $3 \mathrm{~cm}$, and width, consistently less than depth, is up to $2 \mathrm{~cm}$. Burrow fill is of similar grain size to host rock.

Remarks. T. rectus, the most commonly reported ichnospecies of the ichnogenus Teichichnus, is characterised by its vertical or near vertical, relatively straight unbranched retrusive spreite without evidence of backfill. One specimen (fig. 14a) is slightly curved and therefore somewhat resembles $T$. flexuosus Schneider, 1962; this latter ichnospecies, however, tends to be more sinuous in plan view.

\section{Epichnial grooves}

Fig. 14d

Material. At least twenty specimens from GGU collections 239665-14, 239665-21, 239665-22, 314834-14, 314834-15, 314834-18, 314834-19, 239916-2, 239918-3, 239607-2.

Description. All specimens are preserved in negative epirelief and consist of simple, straight, curved or tortuous, unbranched, grooves, impressed 1 to $2 \mathrm{~mm}$ below stratification planes. The grooves are flat-bottomed, smooth and structureless and of variable dimensions, up to $1 \mathrm{~cm}$ in width and $20 \mathrm{~cm}$ in length. Width is relatively constant throughout individual specimens. Gently convex marginal ridges, $1 \mathrm{~mm}$ in width and height above the stratification planes, are commonly present but may be absent.
Remarks. It is impossible to determine from the preservational style whether these structures represent the basal sections of eroded and, or, collapsed burrows, or whether they represent former surficial trails. Specimens with marginal ridges strongly resemble collapsed portions of Palaeophycus tubularis as described herein. However, the absence of definitive morphological criteria precludes assignment even at the ichnogeneric level.

\section{Pit and mound structures}

Fig. 15a

Material. Nine specimens from GGU collections 314834-14, 314834-15, 239665-20.

Description. Specimens are preserved on upper sandstone surfaces as elliptic mounds ( 2 specimens) in positive epirelief or depressions ( 7 specimens) in negative epirelief. Individual ellipses range from $2.3 \mathrm{~cm}$ by 1.1 cm to $3.7 \mathrm{~cm}$ by $2.1 \mathrm{~cm}$; the mean is $2.9 \mathrm{~cm}$ by $1.8 \mathrm{~cm}$. Mounds are composed of sandstone of similar grain size to the enclosing host rock; pits possess a fill of muddy sandstone, commonly with a swirl-like concentric structure and slightly elevated marginal sandstone rims, elevated 1 to $3 \mathrm{~mm}$ above the stratification planes. Transverse sectioning reveals that the structures are surface expressions of massive or concentrically ornamented, v-shaped, vertical disturbance zones which extend downwards, typically eccentrically (fig. 15), for at least $1.4 \mathrm{~cm}$. Specimens do not exhibit a consistent vertical morphology; several simply terminate at the base of the eccentric v-shaped disturbance zone, whereas others exhibit evidence of underlying, essentially vertically oriented, biogenic activity. Fig. 15 illustrates such a specimen in which this underlying basal portion of the burrow possesses an incipient spreite similar to that of Teichichnus and laminae of the enclosing host rock are clearly deflected downwards.

Remarks. These structures are regarded as biogenic in origin as they bear no morphological resemblance to inorganically-produced (e.g. dewatering) structures. Although internally complex and variable, we group them collectively as pit and mound structures which is their typical upper surface expression. Upper surface expressions as pits surrounded by slightly raised sand-

Fig. 14. a-c, Teichichnus rectus shown in vertical cross-section (a and c) and vertical longitudinal section (b). a is MGUH 19.690 from GGU collection 239922-1 and $b$ and c represent MGUH 19:691 from GGU collection 239922-2. The basal surface of the polished face in a is illustrated in fig. 4c, d, epichnial groove with well developed convex marginal ridges, MGUH 19.692 from GGU collection 239601-2. 


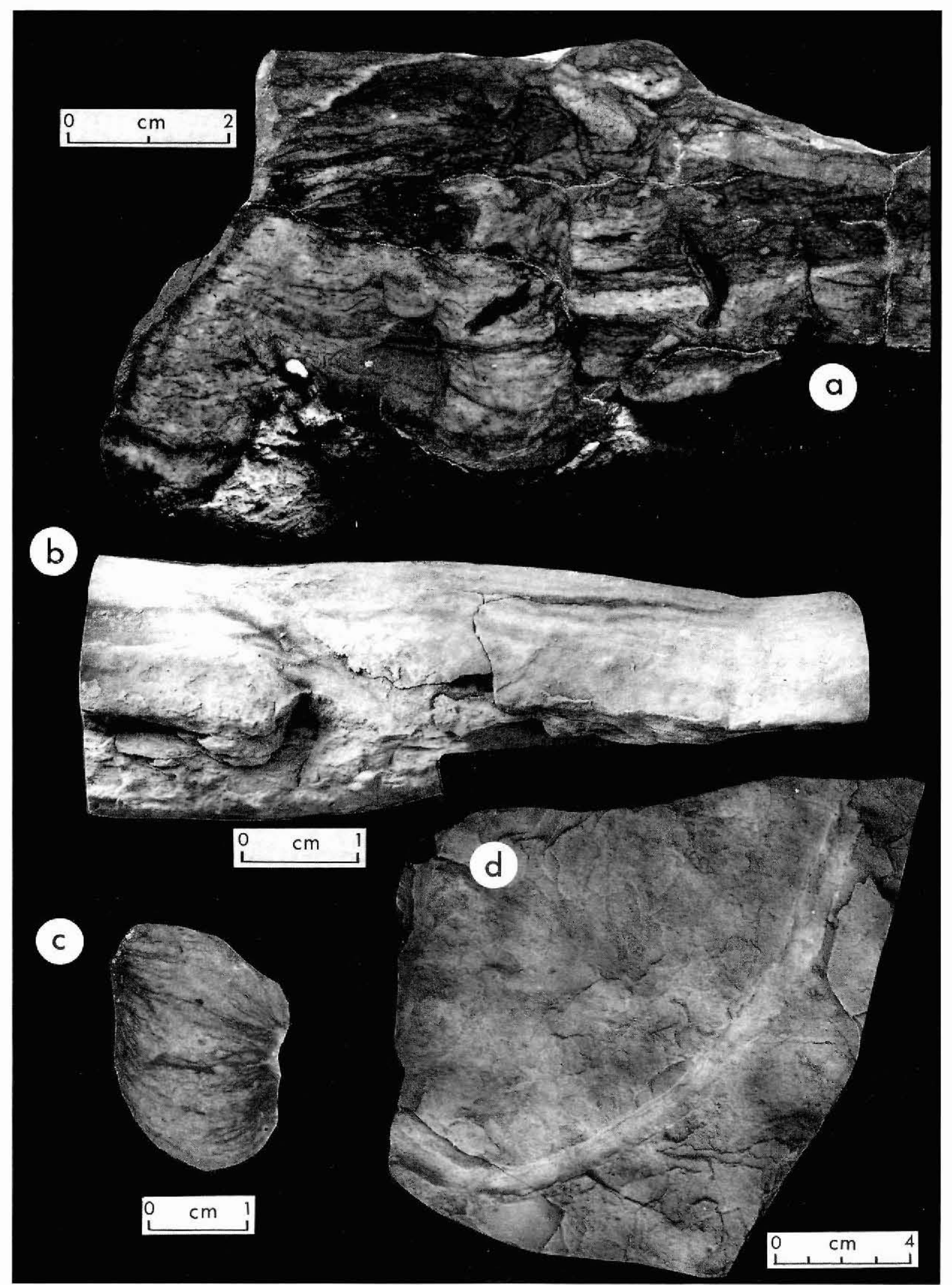




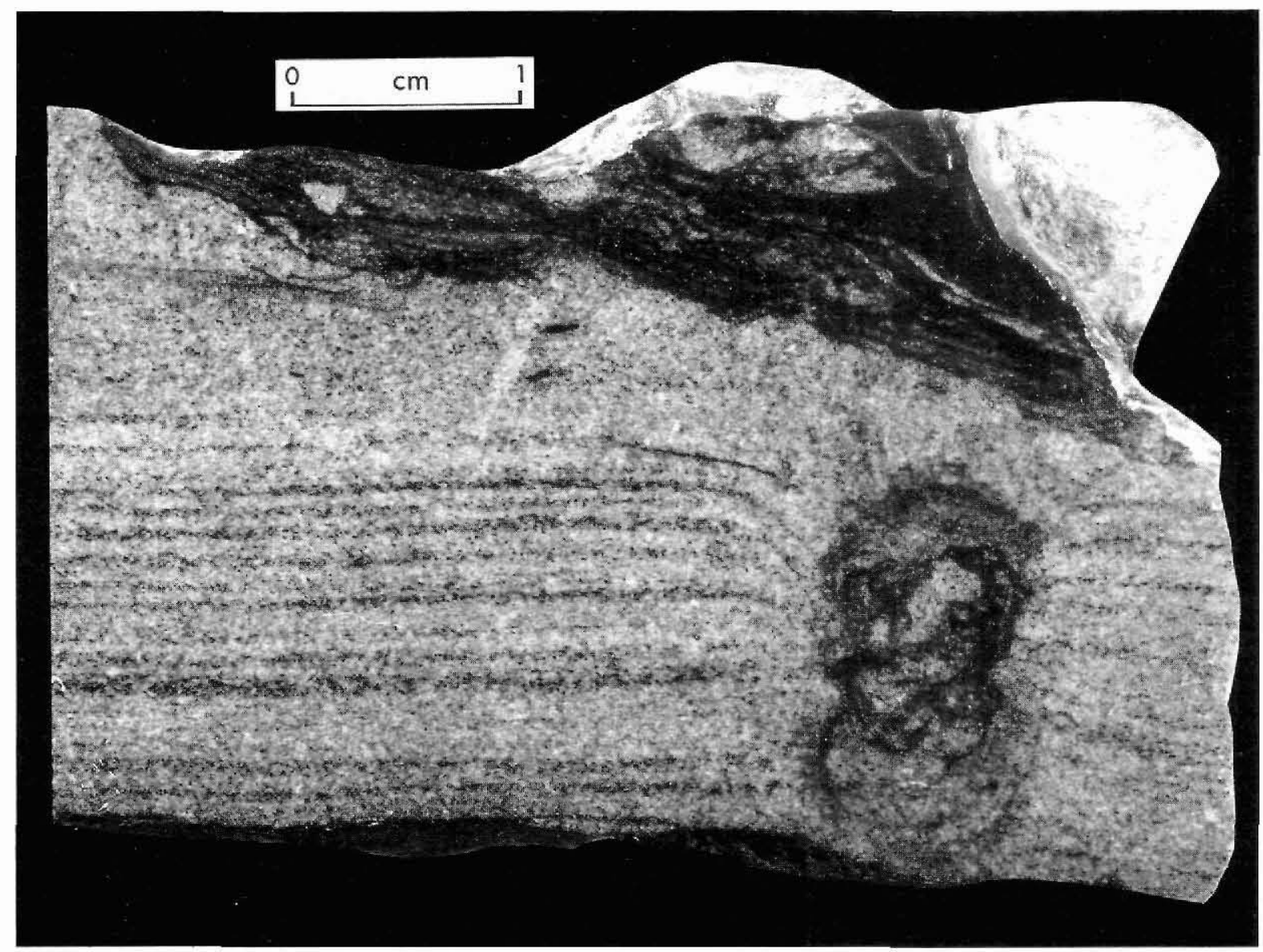

Fig. 15. Vertical cross-sectional view of a pit and mound structure underlain at the right by Teichichnus-like vertical spreite. Note the eccentric $\mathrm{V}$-shaped disturbance zone with its concentric mudstone fill.

stone rims bear a vague resemblance to Lingulichnus Hakes, 1976, as figured by several previous authors (e.g. Durand, 1984; Fillion \& Pickerill, 1990). However, the complex and morphologically variable transverse sections bear no resemblance to this ichnogenus which, incidentally, has only previously been recorded from a single example from Cambrian strata (Pemberton \& Kobluk, 1978). We know of no previously reported comparable analogues of these specimens and, in view of the relatively limited material which is itself not sufficiently morphologically distinct to warrant formal taxonomic treatment, we prefer to describe them informally.

\section{Discussion and conclusions}

This contribution is intended essentially as a more complete analysis and taxonomic treatment of trace fossils available from the Bastion Formation. Although representatives of 19 ichnogenera (25 ichnospecies) and
2 vernacular ichnotaxa are described, we believe that further sampling will reveal additional forms and will undoubtedly result in a more refined taxonomic evaluation. In part, this is because the collections were made randomly with no view to a thorough ichnological analysis. As the ichnospecies list (fig. 2) demonstrates, the more diverse and confidently identified material is present in the larger collections. Thus, the spatial and temporal variability of the ichnotaxa may not be realistic.

In our analysis we have usually avoided any discussion of potential producers of the described ichnotaxa because such information is available in many of the cited publications and in monographic studies (e.g. Frey, 1970; Osgood, 1970; Hakes, 1976; Książkiewicz, 1977; Durand, 1984; Fillion \& Pickerill. 1990) or special symposia on trace fossils (e.g. Crimes \& Harper, 1970. 1977; Miller et al., 1984; Curran, 1985). It is clear from a review of these publications that although body fossils are not reported from the Lower Bastion Formation, a 
variety of organisms inhabited the shallow marine substrates during its formation. These include arthropods, responsible for the production of Cruziana, Dimorphichnus, Monomorphichnus and Rusophycus, possible molluscs, responsible for Plagiogmus and Psammichnites, anthozoans, responsible for Bergaueria, and a variety of annelids that probably produced the remaining ichnotaxa described here. Such metazoans were obviously present in many Early Cambrian, pre-trilobite, shallow shelf areas as similarly suggested by their contained ichnofaunal assemblages.

Crimes $(1987,1989)$ recently reviewed the global occurrence of Lower Cambrian pre-trilobite shallow shelf successions and provided an extensive discussion of their contained trace fossils. The great majority of the ichnogenera recorded from the Bastion Formation have been reported from many Lower Cambrian successions (see Crimes, 1987, fig. 5). Treptichnus, reported by Fritz \& Crimes (1985) and Crimes (1987; the 'feather stitch trails' of Cowie \& Spencer (1970)), has not been recorded in the present collections, but also clearly falls within this category of well documented forms. Only Cylindrichnus and Rosselia were not considered by Crimes (1987) and are apparently rare forms in Lower Cambrian strata. Rosselia has been recorded, however, from the Lower Cambrian of the Salt Range of Pakistan by Seilacher (1955). The absence of Cylindrichnus is more enigmatic but may be due to the fact that although originally erected in 1966 , it was only more clearly defined in 1985 by Frey \& Howard, who were also the first to designate types. Most literature reviewed by Crimes (1987) pre-dates this publication and therefore the absence of Cylindrichnus may not be real; possible examples could have been previously identified as an alternative ichnotaxon, particularly Skolithos.

Considerable interest has been expressed during the last two decades in stratigraphic sections containing late Proterozoic and Early Cambrian transitional sequences, particularly for the purpose of defining the base of the Cambrian (Cowie \& Brasier, 1989; Hofmann \& Patel, 1989). Although a variety of fossil groups occur in the Precambrian-Cambrian transition most research has focused on small shelly fossils and trace fossils (e.g. Narbonne $e t$ al., 1987; Landing $e t$ al. 1989). The stratigraphic succession of early skeletalised metazoans has been in primary focus (cf. Cowie \& Brasier, 1989) but, despite substantial advances in the study of these small shelly fossils, major problems remain in the interpretation of their palaeobiology, palaeontology and evolutionary history (Brasier, 1986; Conway. Morris, 1987; Narbonne et al., 1987; Cowie \& Brasier, 1989; see also Crimes, 1987, 1989).

Trace fossils have several significant advantages over shelly fossils, particularly with respect to international correlation of the boundary interval. First, trace fossils are easily found and collected and most are easily identifiable at the ichnogeneric level (Crimes, 1989). Second, trace fossils are cosmopolitan in contrast to shelly faunas, many of which are decidedly provincial. Third, trace fossils always occur in situ and are not subject to secondary transportation. Fourth, several trace fossils have a restricted stratigraphical range and seem to have a regular order of first appearance at widespread locations (Crimes, 1989). Fifth, although essentially restricted to siliciclastic sequences spanning the boundary interval, trace fossils can also occur in carbonate facies (e.g. Jiang et al., 1982; Crimes \& Jiang, 1986; Fedonkin, 1987); therefore, unlike shelly fossils, trace fossils are facies-crossing (Narbonne \& Myrow, 1988).

The importance of low-diversity assemblages of morphologically simple trace fossils in Precambrian strata, compared to the more diverse and complex assemblages within Early Cambrian strata, has long been recognised (for references, see Crimes, 1987, 1989; Narbonne et al., 1987). Yet it is only relatively recently that zonal schemes for boundary-interval trace fossils have been proposed. The first such scheme, proposed by Jiang et al. (1982) from the boundary candidate at Meishucun in Yunnan province, China, has not generally received universal acceptance, as the lowermost two zones, in ascending order, the Precambrian Sellaulichnus meischucunensis and Cavaulichnus viatorus Zones, are based on non-diagnostic or poorly preserved material (Narbonne \& Myrow, 1988). The uppermost two zones, in ascending order the Didymaulichnus miettensis and Plagiogmus arcuatus Zones, contain more typical Cambrian-type trace fossils but again are probably only locally significant; they were not even considered by Crimes \& Jiang (1986) and Crimes (1987) in their more detailed discussion of the ichnology of the Meischucun section.

More recently Crimes $(1987,1989)$ proposed a truly global trace fossil zonation and recognised three zones of latest Precambrian and earliest Cambrian (sub-trilobite) trace fossils. These zones, based essentially on the first appearance and not the stratigraphic range of the trace fossils are:

Ichnofossil Zone I. Late Vendian. Composed of simple, horizontal or subhorizontal ichnogenera (e.g. Cochlichnus, Didymaulichnus, Gordia, Neonereites, Scolicia) with fewer vertical traces (e.g. Arenicolites, Skolithos). Several ichnogenera (e.g. Bilinichnus, Harlaniella, Intrites, Nenoxites, Palaeopascichnus, Vendichnus, Vimenites) are apparently restricted to this zone. 
Ichnofossil Zone II. Early Tommotian. Contains the first appearance of more complex and deeper burrowing ichnogenera (e.g. Bergaueria, Diplocraterion, Phycodes, Teichichnus, Treptichnus). All ichnogenera occur in younger strata.

Ichnofossil Zone III. Late Tommotian - early Atdabanian. Contains a considerably more diverse ichnofauna with the first appearance of arthropod traces (e.g. Cruziana, Diplichnites, Dimorphichnus, Monomorphichnus, Rusophycus) and spreiten-dwelling burrows (e.g. Diplocraterion). Ichnogenera such as Astropolichnus and Plagiogmus are considered to be restricted to this zone, though as previously noted, the latter has a more extensive stratigraphic range.

Narbonne et al. (1987) and Narbonne \& Myrow (1988) also recognised three trace fossil zones for boundary-interval trace fossils. These three zones, in ascending order the Harlaniella podolica, Phycodes pedum and Rusophycus avalonensis Zones, were broadly equated with the Ichnofossil Zones I, II and III of Crimes (1987). Based on correlation with sequences containing published reports of small shelly fossils, Narbonne et al. (1987) regarded the $H$. podolica Zone as equivalent to only the upper half of Ichnofossil Zone I of Crimes (1987). The $P$. pedum Zone was equated with Ichnofossil Zone II which they suggested, based on published studies of the Rovno 'Horizon' of the East European Platform and in the Nemakit Daldyn of Siberia, together with their own work in eastern Newfoundland, possibly slightly predated the base of the Tommotian. Finally, the R. avalonensis Zone was correlated with Ichnofossil Zone III of Crimes (1987) but was regarded to range in age from possibly the early or middle Tommotian through the Atdabanian.

Based essentially on the report by Cowie \& Spencer (1970), Crimes $(1987,1989)$ tentatively suggested a late Tommotian to Atdabanian age, equivalent to Ichnofossil Zone III, for the trace fossils of the Lower Bastion Formation. Narbonne \& Myrow (1988, p. 75) regarded the sequence as attributable to the $P$. pedum Zone, that is, equivalent to Ichnofossil Zone II.

Disregarding the problem in relative ages proposed by these various authors, it is clear that the trace fossil assemblage described here and by Cowie \& Spencer (1970) from the Bastion Formation can be correlated to Ichnofossil Zone III as proposed by Crimes (1987) or the $R$. avalonensis Zone as proposed by Narbonne et al. (1987) and Narbonne \& Myrow (1988). Using data provided by these authors, Arenicolites, Neonereites and possibly Monomorphichnus (Crimes, 1987, p. 104) and Skolithos (but see Narbonne \& Myrow, 1988, p. 74) have been reported from strata as old as Ichnofossil Zone I or the $H$. podolica Zone. Ichnofossil Zone II, the $P$. pedum Zone, and younger strata have been reported to contain Bergaueria, Gyrolithes, Helminthopsis, Monomorphichnus, Palaeophycus, Phycodes, Skolithos and Treptichnus. The remaining ichnogenera make their first appearance in Ichnofossil Zone III or the $R$. avalonensis Zone. Clearly the entire assemblage from the Bastion Formation can be correlated to this latter zone, which is in accord with the conclusion of Crimes (1987, 1989).

The precise age of the Bastion Formation is difficult to assess. The Upper Bastion Formation has yielded olenellid and eodiscid trilobites, brachiopods, molluscs, hyoliths and bradoriids (Cowie \& Adams, 1957; Cowie \& Spencer, 1970) of Atdabanian or younger age. The underlying Lower Bastion Formation has not yielded body fossils but contains an extensive trace fossil assemblage (fig. 2) equivalent to Ichnofossil Zone III of Crimes $(1987,1989)$ or the $R$. avalonensis Zone of Narbonne et al. (1987) and Narbonne \& Myrow (1988). As noted above, there is still some confusion regarding the exact age of the lower limit of these zones and considerably more research is required before general agreement can be reached. Nevertheless, we regard the Lower Bastion Formation to be late Tommotian to early Atdabanian, possibly entirely Atdabanian, based on a combination of the following observations:

1. The Lower Bastion Formation is overlain by Atdabanian or younger Lower Cambrian strata of the Upper Bastion Formation.

2. Crimes (1987, p. 105) noted that the general order of appearance of arthropod traces in Ichnofossil Zone III is, in ascending order, Monomorphichnus, Diplichnites, Rusophycus and Cruziana, and that Rusophycus and Cruziana are generally first encountered not far below the first trilobites. The occurrence of Cruziana in the lowermost few metres of the Lower Bastion Formation suggests, therefore, that the entire ichnoassemblage extends well into Ichnofossil Zone III.

3. The overall trace fossil assemblage is relatively diverse; comparison with other sequences of broadly comparable age (see Crimes, 1987, 1989) suggests that the range of behavioural activity represented in the Lower Bastion Formation is clearly reminiscent of other late Tommotian or, more specifically, Atdabanian sequences.

Acknowledgements. We thank P. Frykman and M. P. Smith for collecting or assisting in the collection of much of the described material. T. L. Harland provided transportation and photographed specimens located at the University of Bristol. D. 
Fillion is acknowledged for reading an initial version of the manuscript and providing relevant, particularly historical, literature. R. G. Bromley kindly reviewed the manuscript and provided many thoughtful comments; the use of isp. instead of ichnosp. as the standard abbreviation of ichnospecies follows his suggestion. Technical assistance during the preparation of the manuscript was provided by A. Gomez, R. McCulloch, D. Tabor and the Geological Survey of Greenland.

\section{References}

Alpert, S. P. 1974: Systematic review of the genus Skolithos. J. Paleont. 48, 661-669.

Alpert, S. P. 1976: Trilobite and star-like trace fossils from the White-Inyo Mountains, California. J. Paleont. 50, 226-239.

Badve, R. M. \& Ghare, M. A. 1978: Jurassic ichnofauna of Kutch - I. Biovigyanam 4, 125-140.

Baldwin, C. T. 1977: The stratigraphy and facies associations of trace fossils in some Cambrian and Ordovician rocks of north western Spain. In Crimes, T. P. \& Harper, J. C. (edit.) Trace fossils 2. Geol. J. Spec. Issue 9, 9-40. Liverpool: Seel House Press.

Bandel, K. 1973: Trace fossils from the Upper Devonian Nehden Siltstone of Wuppertal-Barmen (Nordrhein - Westfalen, Germany). Palaeontogr. A 142, 156-176.

Banks, N. L. 1970: Trace fossils from the late Precambrian and Lower Cambrian of Finnmark, Norway. In Crimes, T. P. \& Harper, J. C. (edit.) Trace fossils. Geol. J. Spec. Issue 3, 19-34. Liverpool: Seel House Press.

Barbour, I. H. 1892: Note on new gigantic fossils. Science 19, 99-100.

Bather, F. A. 1925: U-shaped markings on estuarine sandstone near Blea Wyke. Proc. Yorkshire Geol. Soc. 20, 185-199.

Bergström, J. 1973: Organization, life and systematics of trilobites. Fossils and Strata 2, 69 pp.

Bergström, J. 1976: Lower Palaeozoic trace fossils from eastern Newfoundland. Can. J. Earth Sci. 13, 1613-1633.

Bergström, J. \& Ineson, J. R. 1988: The arthropod trail Multipodichnus from the upper Middle Cambrian (Holm Dal Formation) of central North Greenland. Meddr Grønland Geosci. 20, 113-117.

Bergström, J. \& Peel, J. S. 1988: Lower Cambrian trace fossils from northern Greenland. Rapp. Grønlands geol. Unders. 137, 43-53.

Binney, E. W. 1852: On some trails and holes found in rocks of the Carboniferous strata, with remarks on Microconchus carbonarius. Mem. Proc. Manchester Lit. Phil. Soc. 10, 181201

Bornemann, J. G. 1889: Über den Buntsandstein in Deutschland und seine Bedeutung für die Trias. Beiträge Geol., Palaeontol. 1, 61 pp.

Bromley, R. G. \& Asgaard, U. 1979: Triassic freshwater ichnocoenoses from Carlsberg Fjord, east Greenland. Palaeogeogr., Palaeoclimatol., Palaeoecol. 28, 39-80.

Bromley, R. G. \& Frey, R. W. 1974: Redescription of the trace fossil Gyrolithes and taxonomic evaluation of Thalassinoides, Ophiomorpha and Spongeliomorpha. Bull. Geol. Soc. Denmark 23, 311-335.
Brasier, M. D. 1986: The succession of small shelly fossils (especially conoidal microfossils) from English Precambrian - Cambrian boundary beds. Geol. Mag. 123, 237-256.

Brasier, M. D., Hewitt, R. A. \& Brasier, C. J. 1978: On the Late Precambrian - Early Cambrian Hartshill Formation of Warwickshire. Geol. Mag. 115, 21-36.

Bryant, I. D. \& Pickerill, R. K. 1990: Lower Cambrian trace fossils from the Buen Formation of central North Greenland: preliminary observations. Rapp. Grønlands geol. Unders. 147 (this volume).

Chamberlain, C. K. 1971: Morphology and ethology of trace fossils from the Ouachita Mountains, southeast Oklahoma. J. Paleont. 45, 212-246.

Chaplin, J. R. 1980: Stratigraphy, trace fossil associations, and depositional environments in the Borden Formation (Mississippian), northeastern Kentucky. Kentucky Geol. Soc., Annual Fall Field Trip Guidebook, 114 pp.

Clifton, H. E. \& Thompson, J. K. 1978: Macaronichnus segregatis; a feeding structure of shallow marine polychaetes. $J$. Sed. Petrol. 48, 1293-1302.

Cloud, P. \& Bever, J. E. 1973: Trace fossils from the Flathead Sandstone, Fremont County, Wyoming, compared with Early Cambrian forms from California and Australia. $J$. Paleont. 47, 883-885.

Conway Morris, S. 1987: Metazoan evolution near the Precambrian-Cambrian boundary: use and misuse of small shelly fossils. In Landing, E., Narbonne, G. M. \& Myrow, P. (edit.) Trace fossils, small shelly fossils and the Precambrian-Cambrian Boundary. N.Y. State Univ., N.Y. State Museum/Geol. Surv. Bull. 463, 9 (only).

Cowie, J. W. 1971: The Cambrian of the North American arctic regions. In Holland, C. H. (edit.) Lower Palaeozoic rocks of the World. 1. Cambrian of the New World, 325-383. London: Wiley-Interscience.

Cowie, J. W. \& Adams, P. J. 1957: The Geology of the Cambro-Ordovician rocks of central east Greenland. Part I. Stratigraphy and structure. Meddr. Grønland 153(1), 193 pp. Cowie, J. W. \& Brasier, M. D. 1989 (edit.): The PrecambrianCambrian Boundary. Oxford Monogr. Geol. Geophys. 12, 213 pp.

Cowie, J. W. \& Spencer, A. M. 1970: Trace fossils from the late Precambrian/Lower Cambrian of East Greenland. In Crimes, T. P. \& Harper, J. C. (edit.) Trace fossils. Geol. J. Spec. Issue 3, 91-100. Liverpool: Seel House Press.

Crimes, T. P. 1970: Trilobite tracks and other trace fossils from the Upper Cambrian of North Wales. Geol. J. 7, 47-68.

Crimes, T. P. 1987: Trace fossils and correlation of late Precambrian and early Cambrian strata. Geol. Mag. 124, 97119.

Crimes, T. P. 1989: Trace fossils. In Cowie, J. W. \& Brasier, M. D. (edit.) The Precambrian-Cambrian Boundary. $O x$ ford Monogr. Geol. Geophys. 12, 166-185.

Crimes, T. P. \& Anderson, M. M. 1985: Trace fossils from Late Precambrian - Early Cambrian of southeastern Newfoundland (Canada): temporal and environmental implications. J. Paleont. 59, 310-343.

Crimes, T. P. \& Harper, J. C. 1970 (edit.): Trace fossils. Geol. J. Spec. Issue 3, 536 pp. Liverpool: Seel House Press. 
Crimes, T. P. \& Harper, J. C. 1977 (edit.): Trace fossils 2. Geol. J. Spec. Issue 9, 351 pp. Liverpool: Seel House Press.

Crimes, T. P. \& Jiang Zhiwen 1986: Trace fossils from the Precambrian-Cambrian boundary candidate at Meischucun, Jinning, Yunnan, China. Geol. Mag. 123, 641-649.

Crimes, T. P., Legg, I., Marcos, A. \& Arboleya, M. 1977: ?Late Precambrian - low Lower Cambrian trace fossils from Spain. In Crimes, T. P. \& Harper, J. C. (edit.) Trace fossils 2. Geol. J. Spec. Issue 9, 91-138. Liverpool: Seel House Press.

Curran, H. A. 1985 (edit.): Biogenic structures: their use in interpreting depositional environments. Soc. Econ. Pal. Mineral. Spec. Pub. 35, 347 pp.

Dahmer, G. 1937: Lebensspuren aus dem Taunusquarzit und den Siegener Schichten (Unterdevon). Preuss. Geol. Landesant., Jahrb. 57, 523-539.

D'Alessandro, A. \& Bromley, R. G., 1986: Trace fossils in Pleistocene sandy deposits from Gravina area, southern Italy. Riv. It. Paleont. Strat. 92, 67-102.

D'Alessandro, A. \& Bromley, R. G. 1987. Meniscate trace fossils and the Muensteria - Taenidium problem. Palaeontology 30, 743-763.

Dawson, J. W. 1873: Impressions and footprints of acquatic animals and imitative markings on Carboniferous rocks. Amer. J. Sci. Arts 105, 16-24.

Durand, J. 1985: Le Grès Armoricain. Sédimentologie - Trace fossiles. Milieux de dépôt. Centre Armoric. d'étude struct. des Socles, Mém. et Doc. 3, 119 pp.

Eagar, R. M. C., Baines, J. G., Collinson, J. D., Hardy, P. G., Okolo, S. A. \& Pollard, J.E . 1985: Trace fossil assemblages and their occurrence in Silesian (Mid-Carboniferous) deltaic sediments of the Central Pennine Basin, England. In Curran, H. A. (edit.) Biogenic structures: their use in interpreting depositional environments. Soc. Econ. Pal. Mineral. Spec. Pub. 35, 99-149.

Eichwald, K. E. I. von. 1860: Lethaea rossica ou paléontologie de la Russie I., 1657 pp. Stuttgart: E. Schweizerbart.

Ekdale, A. A., Bromley, R. G. \& Pemberton, S. G. 1984: Ichnology. The use of trace fossils in sedimentology and stratigraphy. Soc. Econ. Pal. Mineral. Short Course 15, 317 pp.

Elliot, T. 1986: Siliciclastic shorelines In Reading, H. G. (edit.) Sedimentary environments and facies, 155-188. Oxford: Blackwell

Emmons, E. 1844: The Taconic System, based on observations in New York, Massachusetts, Maine, Vermont and Rhode Island, 68 pp. Albany: Carroll \& Cook.

Fedonkin, M. A. 1980: Rannie etapi evoliutsii Metazoa po paleoichnologicheskim dannim. Akad. Nauk SSSR, Ser. Geolog. 2, 226-233.

Fedonkin, M. A. 1988: Paleoichnology of the PrecambrianCambrian transition in the Russian Platform and Siberia. In Landing, E., Narbonne, G. M. \& Myrow, P. (edit.) Trace fossils, small shelly fossils and the Precambrian-Cambrian Boundary. N.Y. State Univ., N.Y. State Museum/Geol. Surv. Bull. 463, 12 (only).

Fenton, C. L. \& Fenton, M. A. 1937a: Olivellites, a Pennsylvanian snail burrow. Am. Midl. Nat. 18, 452-453.
Fenton, C. L. \& Fenton, M. A. 1937b: Burrows and trails from Pennsylvanian rocks of Texas. Am. Midl. Nat. 18, 10791084.

Fenton, C. L. \& Fenton, M. A. 1937c. Trilobite 'nests' and feeding burrows. Am. Midl. Nat. 18, 446-451.

Fillion, D. 1989: Les critères discriminants à l'intérieur du triptyque Palaeophycus - Planolites - Macaronichnus. Essai de synthèse d'un usage critique. C. r. Acad. Sci. Paris, 309, 169-172.

Fillion, D. \& Pickerill, R. K. 1990: Ichnology of the Upper Cambrian(?) to Lower Ordovician Bell Island and Wabana groups of eastern Newfoundland, Canada. Palaeontogr. canadiana 7 (in press).

Fischer, P. \& Paulus, B. 1969: Spurenfossilien aus den Oberen Nohn-Schichten der Blankenheimer Mulde (Eifelium, Eifel). Senckenbergiana lethaea 50, 81-101.

Fitch, A. 1850: A historical, topographical and agricultural survey of the County of Washington. Pt. 2-5. N.Y. Agric. Soc. Trans. 9, 753-944.

Frey, R. W. 1970: Trace fossils of the Fort Hays Limestone Member of Niobrara Chalk (Upper Cretaceous), west-central Kansas. Univ. Kansas Paleont. Contrib. 53, 41 pp.

Frey, R. W. \& Bromley, R. G. 1985: Ichnology of American chalks: the Selma Group (Upper Cretaceous), western Alabama. Can. J. Earth Sci. 22, 801-828.

Frey, R. W. \& Howard, J. D. 1985: Trace fossils from the Panther Member, Star Point Formation (Upper Cretaceous), Coal Creek Canyon, Utah. J. Paleont. 59, 370-404.

Fritsch, A. 1908: Problematica Silurica. In Joachim Barrande, Systême silurien du centre de la Bohême, 28 pp. Prague: published from Barrande Fund by author and editor.

Fritz, W. H. \& Crimes, T. P. 1985: Lithology, trace fossils, and correlation of Precambrian-Cambrian boundary beds, Cassiar Mountains, north-central British Columbia. Geol. Surv. Canada Paper 83-13, 24 pp.

Fürsich, F. T. 1974. Corallian (Upper Jurassic) trace fossils from England and Normandy. Stuttgarter Beit. zur Natur., Serie B (Geol. und Paläont.) 13, 1-51.

Gernant, R. E. 1972: The paleoenvironmental significance of Gyrolithes (Lebensspur). J. Paleont. 46, 735-741.

Ghent, E. D. \& Henderson, R. A. 1966: Petrology, sedimentation and paleontology of Middle Miocene graded sandstones and mudstone, Kaiti Beach, Gisborne. Trans. Roy. Soc. N.Z., Geol. 4, 147-169.

Glaessner, M. F. 1969. Trace fossils from the Precambrian and basal Cambrian. Lethaia 2, 369-393.

Goldring, R. 1962: The trace fossils of the Baggy Beds (Upper Devonian) of North Devon, England. Paläontol. Z. 36, 232251.

Götzinger, G. \& Becker, H. 1932; Zur geologischen Gliederung des Wienerwaldflysches (Neue Fossilfunde). Geol. Bund. Wien Jahrb. 82, 343-396.

Hakes, W. G. 1976: Trace fossils and depositional environment of four clastic units, Upper Pennsylvanian megacyclothems, northeast Kansas. Univ. Kansas Paleont. Contrib. 63, 46 pp.

Haldeman, S. S. 1840: Supplement to number one of 'A monograph of the Limniades, or freshwater univalve shells of North America', containing descriptions of apparently new 
animals in different classes, and the names and characters of the subgenera in Paludina and Anculosa. 3 pp, Philadelphia: J. Dobson.

Hall, J. 1847: Palaeontology of New York, Volume I. Containing descriptions of the Lower Division of the New York System, (equivalent of the Lower Silurian rocks of Europe), 338 pp. Albany: C. van Benthuysen.

Hall, J. 1852: Palaeontology of New York, Volume II. Containing descriptions of the organic remains of the Lower Middle Division of the New York System, (equivalent in part to the Middle Silurian rocks of Europe). 362 pp. Albany: C. van Benthuysen.

Häntzschel, W. 1934: Schraubenförmige und spiralige Grabgänge in turonen Sandstein des Zittauer Gebirges. Senckenbergiana 16, 313-324.

Häntzschel, W. 1962: Trace fossils and Problematica. In Moore, R. C. (edit.) Treatise on invertebrate paleontology W, W177-W245. Lawrence: Geol. Soc. Am. and Kansas Univ. Press.

Häntzschel, W. 1975: Trace fossils and problematica. In Teichert, C. (edit.) Treatise on invertebrate paleontology W. Miscellanea, supplement 1. 269 pp. Lawrence: Geol. Soc. Am. and Kansas Univ. Press.

Henriksen, N. \& Higgins, A. K. 1976: East Greenland Caledonian fold belt. In Escher, A. \& Watt, W. S. (edit.) Geology of Greenland, 182-246. Copenhagen: Geol. Surv. Greenland.

Heer, O. 1876-1877: Flora fossilis Helvetiae. Die vorweltliche Flora der Schweiz. 182 pp. Zurich: J. Würster \& Co.

Heinberg, C. 1970: Some Jurassic trace fossils from Jameson Land (East Greenland). In Crimes, T. P. \& Harper, J. C. (edit.) Trace fossils. Geol. J. Spec. Issue 3, 227-234. Liverpool: Seel House Press.

Heinberg, C. 1973: The internal structure of the trace fossils Gyrochorte and Curvolithus. Lethaia 6, 227-238.

Heinberg, C. \& Birkelund, T. 1984: Trace fossil assemblages and basin evolution of the Vardekløft Formation (Middle Jurassic, central east Greenland). J. Paleont. 58, 362-397.

Hofmann, H. J. \& Patel, I. M. 1989: Trace fossils from the type 'Etcheminian Series' (Lower Cambrian Ratcliffe Brook Formation), Saint John area, New Brunswick, Canada. Geol. Mag. 126, 139-159.

Howard, J. D. 1966: Characteristic trace fossils in Upper Cretaceous sandstones of the Book Cliffs and Wasatch Plateau. Utah Geol. Min. Surv., Central Utah Coal Bull. 80, 35-53.

Howard, J. D. \& Frey, R. W. 1984: Characteristic trace fossils in nearshore to offshore sequences, Upper Cretaceous of east-central Utah. Can. J. Earth Sci. 21, 200-219.

Jaeger, H. \& Martinsson, A. 1980: The Early Cambrian trace fossil Plagiogmus in the type area. Geol. Fören. Stockholm Föhr. 102, 117-126.

Jiang Zhiwen, Luo Huilin \& Zhang Shishan 1982: Trace fossils of the Meishucun Stage (lowermost Cambrian) from the Meishucun Section in China. Geol. Rev. 28, 7-13.

Kruse, P. D. \& West, P. W. 1980: Archaeocyatha of the Amadeus and Georgina Basins. BMR J. Austral. Geol. Geophys. 5, 165-181.

Książkiewicz, M. 1968. O niektórych problematykach z fliszu
Karpat Polskich (Czecz III). Polsk. Towarzyst. Geol, Rocznik 38, 3-17.

Książkiewicz, M. 1977: Trace fossils in the flysch of the Polish Carpathians. Palaeontogr. pol. 36, 208 pp.

Landing, E., Myrow, P., Benus, A. P \& Narbonne, G. M. 1989: The Placentian Series: appearance of the oldest skeletalized faunas in southeastern Newfoundland. J. Paleont. 63, 739-768.

Legg, I. C. 1985: Trace fossils from a Middle Cambrian deltaic sequence, North Spain. In Curran, H. A. (edit.) Biogenic structures: their use in interpreting depositional environments. Soc. Econ. Pal. Mineral. Spec. Pub, 35, 151-165.

Linnarsson, J. G. O. 1869: On some fossils found in the $E o$ phyton sandstone at Lugnas in Sweden. Geol. Mag. 6, 393406.

Lockley, M. G., Rindsberg, A. K. \& Zeiler, R. M. 1987: The Paleonenvironmental significance of the nearshore Curvolithus ichnofacies. Palaois 2, 255-262.

MacLeay, W. S. 1839: Note on the Annelida. In Murchison, R. I. The Silurian System II, 699-701. London: J. Murray.

Macsotay, O. 1967: Huellas problématicas y su valor paleoecológico en Venezuela. Geos (Venezuela) 16, 7-79.

Mägdefrau, K. 1934: Über Phycodes circinatum Reinh. Richter aus dem thüringischen Ordovicium. Neues. Jahrb. Mineral. Geol. Pälaontol. 72, 259-282.

Mansfield, W. C. 1927: Some peculiar fossils from Maryland. Proc. U.S. Nat. Mus. 71, 1-9.

Martinsson, A. 1970: Toponomy of trace fossils. In Crimes T. P. \& Harper, J. C. (edit.) Trace fossils. Geol. J. Spec. Issue 3, 323-330. Liverpool: Seel House Press.

McCarthy, B. 1979: Trace fossils from a Permian shorefaceforeshore environment, eastern Australia. J. Paleont. 53, 345-366.

Miller, M. F. \& Knox, L. W. 1985: Biogenic structures and depositional environments of a Lower Pennsylvanian coalbearing sequence, northern Cumberland Plateau, Tennesee, U.S.A. In Curran, H. A. (edit.) Biogenic structures: their use in interpreting depositional environments. Soc. Econ. Pal. Mineral. Spec. Pub. 35, 67-97.

Miller, M. F., Ekdale, A. A. \& Picard, M. D. 1984 (edit.): Trace fossils and paleoenvironments: marine carbonate, marginal marine terrigenous and continental terrigenous setting. J. Paleont. 58, 283-597.

Miller, S. A. 1880: Silurian ichnolites, with definitions of new genera and species. J. Cincinnati Soc. Nat. Hist. 2, 217-229.

Narbonne, G. M. \& Myrow, P. 1988: Trace fossil biostratigraphy in the Precambrian-Cambrian boundary interval. In Landing, E., Narbonne, G. M. \& Myrow, P. (edit.) Trace fossils, small shelly fossils and the Precambrian-Cambrian Boundary. N. Y. State Univ. N.Y. State Museum/Geol. Surv. Bull. 463, 72-76.

Narbonne, G. M., Myrow, P., Landing, E. \& Anderson, M. M. 1987: A candidate stratotype for the Precambrian-Cambrian boundary, Fortune Head, Burin Peninsula, southeastern Newfoundland. Can. J. Earth Sci. 24, 1277-1293.

Nicholson, H. A. 1873: Contributions to the study of errant annelides of the older Palaeozoic rocks. Proc. Roy. Soc. Lond. 21, 288-290 (also Geol. Mag. 10, 309-310). 
Orbigny, A.'d. 1839: Voyages dans l'Amérique méridionale (le Brésil, la république orientale de l'Uruguay, la république Argentine, la Patagonie, la république du Chili, la république de Bolivie, la république du Pérou), exécuté pendant les années 1826 - 1833, 188 pp. Paris-Strasbourg: Pitois-Levrault, Levrault.

Orlowski, S., Radwanski, A. \& Roniewicz, P. 1970: The trilobite ichnocoenoses in the Cambrian sequence of the Holy Cross Mountains. In Crimes, T. P. \& Harper, J. C. (edit). Trace fossils. Geol. J. Spec. Issue 3, 345-360. Liverpool: Seel House Press.

Osgood, R. G. Jr. 1970: Trace fossils of the Cincinnati area. Paleontogr. Americana 6, 279-444.

Otto, E. von 1854: Additamente zur Flora des Quadergebirges in Sachsen. II. Heft, enthaltend meist noch nicht oder wenig bekannte fossile Pflanzen, 53 pp. Leipzig: G. Mayer.

Peel, J. S. 1982: Lower Palaeozoic of Greenland. In Embry, A. F. \& Balkwill, H. G. (edit.) Arctic geology and geophysics. Mem. Can. Soc. Petrol. Geol. 8, 309-330.

Pemberton, S. G. \& Frey, R. W. 1982: Trace fossil nomenclature and the Planolites - Palaeophycus dilemma. J. Paleont. 56, 843-881.

Pemberton, S. G. \& Kobluk, D. R. 1978: Oldest known brachiopod burrow: the Lower Cambrian of Labrador. Can. J. Earth Sci. 15, 1385-1389.

Pemberton, S. G., Frey, R. W. \& Bromley, R. G. 1988: The ichnotaxonomy of Conostichus and other plug-shaped ichnofossils. Can. J. Earth Sci. 25, 866-892.

Peterson, D. O. \& Clark, D. L. 1974: Trace fossils Plagiogmus and Skolithos in the Tintic Quartzite (Middle Cambrian) of Utah. J. Paleont. 48, 766-768.

Pickerill, R. K. 1989: Bergaueria perata Prantl, 1945 from the Silurian of Cape George, Nova Scotia. Atlantic Geol. 25, 191-197.

Pickerill, R. K. \& Harland, T. L. 1988: Trace fossils from Silurian slope deposits, North Greenland. Rapp. Grønlands geol. Unders. 137, 119-133.

Pickerill, R. K., Hurst, J. M. \& Surlyk, F. 1982: Notes on Lower Palaeozoic flysch trace fossils from Hall Land and Peary Land, North Greenland. Rapp. Grønlands geol. Unders. 108, 25-29.

Plaziat, J.-C. \& Mahmoudi, M. 1988: Trace fossils attributed to burrowing echinoids: a revision including new ichnogenus and ichnospecies. Géobios 21, 209-233.

Pollard, J. E. 1981: A comparison between the Triassic trace fossils of Cheshire and south Germany. Palaeontology 24, 555-588.

Powell, E. N. 1977: The relationship of the trace fossil Gyrolithes (= Xenohelix) to the family Capitellidae (Polychaeta). J. Paleont. 51, 552-556.

Prantl, F. 1945: Dvě záhadné Zklameněliny (stopy). z vrstev chrustenickch - $\mathrm{d} \delta \mathrm{z}$, Rozpravy II. Tridy Ceské Akad. 55, 3-8.

Quatrefages, M. A. de 1849: Note sur la Scolicia prisca (A. de Q.), annélide fossile de la Craie. Ann. Sci. Nat. 12, 265-266.

Richter, R. 1850: Aus der thüringischen Grauwacke. Deutsche Geol. Gesell. Zeitschr. 2, 198-206.
Richter, R. 1853: Gaea von Salfeld. Programm d. Realsch. Saafeld, 3-32.

Roedel, H. 1929: Ergänzung zu meiner Mitteilung über ein kambrisches Geschiebe mit problematischen Spuren. Zeitschr. Geschiebeforschg. 2, 22-26.

Romano, M. \& Whyte, M. A. 1987: A limulid trace fossil from the Scarborough Formation (Jurassic) of Yorkshire; its occurrence, taxonomy and interpretation. Proc. Yorkshire geol. Soc. 46, 85-95.

Sacco, F. 1888: Note di paleoicnologia italiana. Soc. Ital. Sci. Nat. Mus. civ. storia nat. Milano 31, 151-192.

Salter, J. W. 1857: On annelide-burrows and surface-markings from the Cambrian rocks of the Longmynd. Quart. J. geol. Soc. Lond. 13, 199-206.

Saporta, L. C. J. G. de 1884: Les organismes problématiques des anciennes mers., 100 pp. Paris: Masson.

Sarjeant, W. A. S. 1979: Code for trace fossil nomenclature. Palaeogeogr., Palaeoclimatol., Palaeoecol. 28, 147-167 (inadvertently attached to paper by P. B. Basan).

Schindewolf, O. H. 1921: Studien aus dem Marburger Buntsandstein, I, II. Senckenbergiana 3, 33-49.

Schneider, W. 1962: Lebensspuren aus der Gräfenthater Serie (Ordovizium) am Schwarzburger Sattel. Geologie 11, 954 960.

Seilacher, A. 1955: Spuren und Lebensweise der Trilobiten; Spuren und Fazies im Unterkambrium. In Schindewolf, $O$. \& Seilacher, A. (edit.) Beiträge zur Kenntnis des Kambriums in der Salt Range (Pakistan). Akad. Wiss. Lit. Mainz, math.-nat. Kl. 10, 11-143.

Seilacher, A. 1960: Lebensspuren als Leitfossilien. Geol. Rund. 49, 41-50.

Seilacher, A. 1964: Sedimentological classification and nomenclature of trace fossils. Sedimentology 3, 253-256.

Seilacher, A. 1970: Cruziana stratigraphy of 'non-fossiliferous' Palaeozoic sandstones. In Crimes, T. P. \& Harper, J. C. (edit.) Trace fossils. Geol. J. Spec. Issue 3, 447-476. Liverpool: Seel House Press.

Seilacher, A. \& Meischner, D. 1965: Fazies-Analyse in Paläozoikum des Oslo-Gebietes. Geol. Rund. 54, 596-619.

Simpson, S. 1975: Classification of trace fossils. In Frey, R.W. (edit.) The study of trace fossils, 39-54. New York: SpringerVerlag.

Singh, I. B. \& Rai, V. 1983: Fauna and biogenic structures in Krol-Tal succession (Vendian - Early Cambrian), Lesser Himalaya: their biostratigraphic and palaeoecological significance. J. Pal. Soc. India 28, 67-90.

Sowerby, J. 1829: The Mineral Conchology of Great Britain 6, 230 pp. London.

Torell, O. 1868: Bidrag till Sparagmitetagens geognosy och paleontologi. Lunds Univ. Årssk. 4, 1-40.

Torell, O. 1870: Petrifica Suecana Formationis Cambricae Lunds Univ. Årssk 6, 1-14.

Trewin, N. H. 1976: Isopodichnus in a trace fossil assemblage from the Old Red Sandsone. Lethaia 9, 29-37.

Webby, B. D. 1969: Trace fossils (Pascichnia) from the Silurian of New South Wales, Australia. Pälaontol. Z. 43, 81-94.

Webby, B. D. 1983: Lower Ordovician arthropod trace fossils 
from western New South Wales. Proc. Linn. Soc. N.S.W. 107, 59-74.

Weller, S. 1899: Kinderhook faunal studies. I. The fauna of the vermicular sandstone at Northview, Webster County, Missouri. Trans. Acad. Sci. St. Louis 9, 9-51.

Whitaker, J. H. MacD 1979: A new trace fossil from the Ringerike Group, Southern Norway. Proc. Geol. Ass. 91, 85-89.
Woodward, B. B. 1922: On Dinocochlea ingens n. g. n. sp., a gigantic gastropod from the Wealden Beds near Hastings. Geol. Mag. 59, 242-248.

Yochelson, E. L. \& Schindel, D. E. 1978: A reexamination of the Pennsylvanian trace fossil Olivellites. J. Res. U.S. Geol. Surv. 6, 789-796. 